RICHARD VALLANCE JANKE

The Association of Historical Studies

KORYVANTES,

Athens, Greece

vallance22@zoho.com
003.326 .1

930.2:003.071(38)

COBISS.SR-ID 228049420

Original research article

Received: May $17^{\text {th }} 2016$

Accepted: June $20^{\text {th }} 2016$

\title{
THE DECIPHERMENT OF SUPERSYLLABOGRAMS IN LINEAR B
}

\begin{abstract}
In partnership with The Association of Historical Studies, Koryvantes (Athens), we address the phenomenon of the supersyllabogram, which has never been properly identified since the initial decipherment of Mycenaean Linear B in 1952. A supersyllabogram is the first syllabogram, i.e. the first syllable of a major (never minor) economic indicator combined with a closely related ideogram in the four economic sectors of the Mycenaean economy, agricultural, military, textiles and vessels or pottery. With very few exceptions, change the economic sector and you change the meaning of any particular supersyllabogram. Of some 3,500 tablets and fragments from Knossos, about 800 or 23\% contain at least one supersyllabogram and sometimes as many as four or five. The whole point of supersyllabograms is that they are meant to eliminate text on tablets to the greatest possible extent. In a syllabary of 61 syllabograms + one homophone (AI), 36 syllabograms or 59\% are supersyllabograms. Supersyllabograms serve to greatly economize on the precious space available on the tiny inventory tablets in Linear B. Any complete decipherment of Linear B must fully account for the supersyllabogram as a unique phenomenon without which any approach to the interpretation of the Linear B syllabary is squarely compromised.
\end{abstract}

\section{KEYWORDS: MYCENAEAN LINEAR B, SUPERSYLLABOGRAMS, LINEAR B TABLETS, DECIPHERMENT, TRANSLATION, ECONOMY.}

\section{INTRODUCTION THE DECIPHERMENT OF LINEAR B}

Michael Ventris (1922-1956), an architect by profession, but an "amateur" philologist by choice (a real understatement), spent close on three years (1950-1952) of gruelling experimentation struggling to decipher the mysterious syllabary called Linear B. Originally, he had assumed, just like everyone else grappling with the decipherment of the script, right on down from Sir Arthur Evans, that Linear B must be a variant of Etruscan. It was only by dint of patient experimentation, his strict empirical methodology and brilliant assumptions integrating disparate clues, that he finally realized that the Linear B syllabary was in fact a very archaic Greek.

Indeed, by the spring of 1952, in a series of twists and turns not even he could have anticipated, it finally hit him like a thunderbolt that Linear B could not be related to any ancient language other than Greek. On 1 June 1952, in Work Note e 20, he openly surmised, "Are the Knossos and Pylos tablets written in Greek?" He was on the very threshold. Exactly one month later, on 1 July 1952, in a BBC broadcast, he announced to the world that he had cracked the syllabary. You can listen to his startling discovery on UTube, as he reveals that "...during the last few weeks I've 


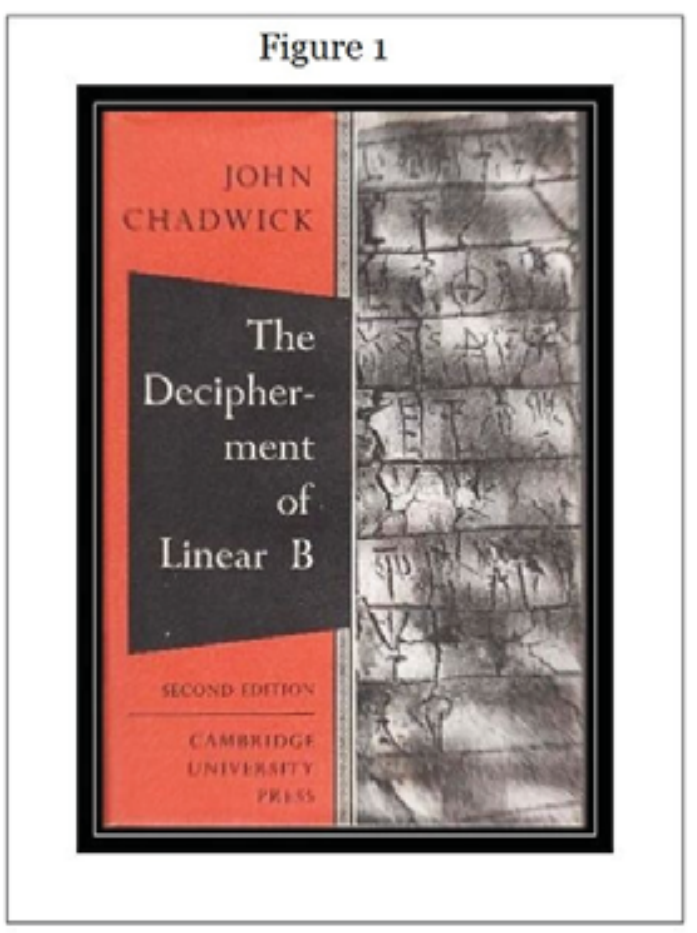

Fig. 1 - The Decipherment of Linear B.

suddenly come to the conclusion that the Knossos and Pylos tablets must, after all, be written in Greek, a difficult and archaic Greek, seeing that it is 500 years older than Homer and written in a rather abbreviated form, but Greek nevertheless..." (italics mine). ${ }^{1}$ However, since he lacked a professional background in Greek philology and linguistics, that same month he turned for support to John Chadwick, an outstanding scholar specializing in ancient Greek and a professor of Classics at the University of Cambridge. Getting on famously, they worked as a highly effective team in the continuing refinement of Ventris' original decipherment, and were able to decipher numerous tablets from both Pylos and Knossos.

But the tablet which stole the show was Pylos TA 641-1952. You can read all about its deci-

1 You can listen to Ventris' startling discovery, as he announces that "... during the last few weeks I've suddenly come to the conclusion that the Knossos and Pylos tablets must, after all, be written in Greek, a difficult and archaic Greek, seeing that it is 500 years older than Homer and written in a rather abbreviated form, but Greek nevertheless..." BBC News http://www.bbc.com/news/magazine-22799109. pherment in great detail in my article in this same journal last year, No. 10 (2014) (Vallance 2016) Ventris' decipherment of this tablet, unearthed by Prof. Carl Blegen at Pylos earlier in 1952, is nothing short of brilliant. Without recourse to his translation of this highly informative Linear B tablet on vessels and pottery, the most famous of all Linear B tablets to date, any close to definitive decipherment would have been unthinkable.

Sadly, Ventris died in an automobile accident a few weeks before the publication of his crowning work, Documents in Mycenaean Greek. This left Prof. John Chadwick (1920-1998) in the unenviable position of having to plot the progress towards the decipherment made by his intimate friend, Michael Ventris. This he did with his seminal work, The Decipherment of Linear B (1958, 1970) (Chadwick 1970).

Prelude to the Discovery of Supersyllabograms in Mycenaean Linear B: so-called "adjuncts":

Shortly after the initial decipherment of Linear B in 1952-1953, researchers gradually came to realize that there was more to the decipherment than merely words comprised of syllabograms. There in fact appeared a substantial number of single syllabograms on $800+$ Linear B tablets from Knossos, of which many were directly linked with an ideogram, while others were incised inside ideograms. This proved to be a real puzzlement to researchers, right on down from Prof. John Chadwick through to the most recent philologists in the second decade of the twenty-first century. Though all of these professional linguists have grappled with this phenomenon, none has been quite able to get a firm handle on what it is tantamount to.

Beginning with Prof. John Chadwick himself (Chadwick 1987) we immediately see single syllabograms either directly linked with an ideogram or incised inside ideograms in this cutaway I made from his chart of Linear B (Fig. 2).

In 1959 he correctly identified 15 of these single syllabograms concatenated with ideograms (a o u di ki ku pe pu qa qe ri se te ti \& zo), attempting to decipher only a few, without realizing what they 


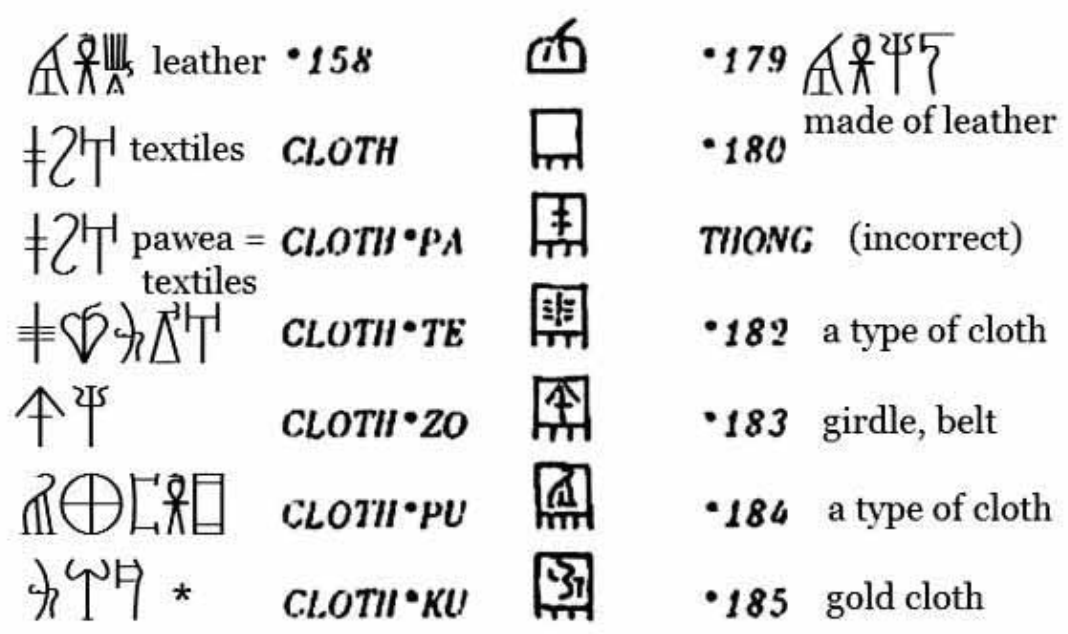

* Actual values of supersyllabograms as established by myself.

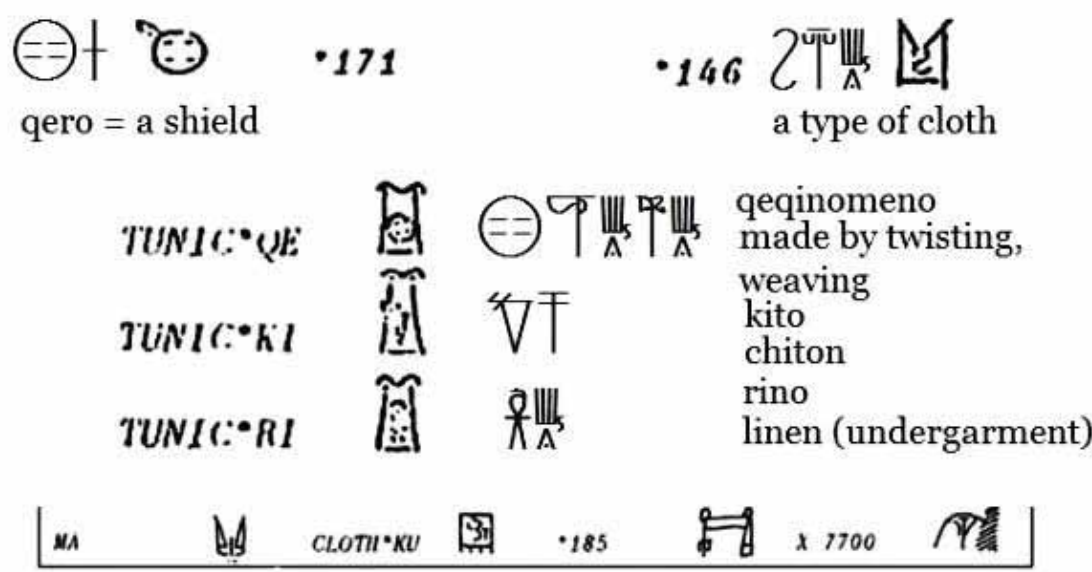

(Chadwick. John. Linear B related scripts. London, 1989.)

(C) by Richard Vallance Janke 2016

Fig. 2 - "Supersyllabograms" identified by John Chadwick.

constituted as a phenomenon. Again, in 1964, Prof. breakthrough in his paper, "Olive Oil and Other John T. Killen, "in a brilliant piece of deduction", Sorts of Oil on the Mycenaean Tablets" (1974) deciphered 4 of these rogue single syllabograms, ki, ne, pe \& za, all in the field of sheep husbandry, again without realizing what they actually were. Here Chadwick concludes, "The mysterious abbreviations were thus solved by Killen..." (italics mine). We still see that as yet neither Chadwick nor Killen had divined what these "mysterious abbreviations" were supposed to amount to.

But that was soon to change. In an astounding

2 Bibliography: Chadwick, John 1976: 128. With the exception of KI, which Prof. Killen incorrectly construed as meaning "lambs", instead of the correct kitimena = "a plot of land", all of his interpretations are in agreement with mine. See supra, Table 6, Supersyllabograms in the agri(Melena 1974) an historical turning point, Prof. José L. Melena deciphered (though not always correctly), the following single syllabograms directly associated with the ideogram for 'olive oil': A KU PA SI TI and WE. His translations and my own reinterpretations of them, where applicable, figure prominently in this study. For the first time ever, the term "adjunct" is utilized. Prof. Melena had finally come up with a nomenclature for this phenomenon. Much later on, in 2014, Prof. Melena once again identified and translated a significant number of "adjuncts" (Melena 2014) arraying them hand in hand with ideograms in the same cultural sector of Mycenaean Linear B. 
class by amalgamating them with the latter. In so doing, he effectively downplayed the critical rôle of supersyllabograms in his fuller decipherment of Linear B tablets. In addition, these researchers have made telling contributions to the decipherment of so-called "adjuncts": Chris Tselentis (Tselentis 2011), Carlos Varias García ${ }^{3}$ and above all, Marie Louise B. Nosch, ${ }^{4}$ the last of whom brought significant advances to the decipherment of "adjuncts" in the textiles sector in which she specialized. Without their splendid contributions, I would never have come to extrapolate their findings to the General Theory of Supersyllabograms.

Single syllabograms are not just "adjuncts": they are supersyllabograms. The question is, if all of these single syllabograms condign with ideograms are not merely adjuncts, how did I come to realize that they were much more, that they were in fact what I have chosen to call "supersyllabograms"? But what is a supersyllabogram? Supersyllabograms are my own definition for what previous researchers have all tagged as "(surcharged) adjuncts". While most supersyllabograms appear to be mere "adjuncts", none are by nature, and many are not adjuncts at all. The systematic isolation, identification and classification in every major sector of the Minoan/Mycenaean economy of what I call supersyllabograms is nothing short of revolutionary in the field of decipherment of Mycenaean Linear B. Allow me to demonstrate graphically in simple terms what a supersyllabogram actually is (Fig. 3):

Closely examining the facsimile of the actual tablet presented here, Knossos KN 791 G c 101, we note right off the top that, with the sole exception of the shepherd's or flock owner's name, Sfakosos, it contains no cursive text. What is going on here? Are these two so-called "adjuncts", KI \& O, simply

3 For Carlos Varias García, see Bibliography: Vallance Janke, Richard 2015. In the extremely comprehensive bibliography to this presentation, consisting of 144 items, Carlos Varias García is cited from 41-45.

4 For Marie Louise Nosch, see Bibliography: Del Freo, Maurizio, Nosch, Marie-Louise and Rougemont, Françoise 2010. that and nothing more? Very far from it. They are "adjuncts" only insofar as they immediately precede the ideograms with which they are directly associated. They are not even "surcharged" the term by preference par excellence which all researchers to date have erroneously dubbed as just that. But the term surcharged implies that these so-called adjuncts are situated above (on top, or either to the left or right) of the ideograms they modify, which in this case and the vast majority of others, they most certainly are not. So even on this count alone, the term "surcharged adjunct" is a contradiction in terms, thereby invalidating the very notion. Moreover, adjuncts in and of themselves are merely subsets of supersyllabograms, rather than the converse. Supersyllabograms are only occasionally adjuncts, while all adjuncts are subsets of supersyllabograms. Once more, the concept of the adjunct invalidates itself, except at its own highly restrictive level as a subset of the supersyllabogram. And that is precisely what the syllabograms $\mathrm{KI} \& \mathrm{O}$ on this tablet are, supersyllabograms, where $\mathrm{KI}=$ kitimena = a plot of land and $\mathrm{O}=$ onato $=\mathrm{a}$ usufruct lease field.

What we have here on this downsized, abbreviated tablet is a double set of two supersyllabograms, KI \& O. What then does the tablet "mean"? You can plainly see for yourself in Figure 3 above. What we have here is the deployment of supersyllabograms alone without any text on a given Linear B tablet - and this happens over and over and over on hundreds of tablets. This is nothing short of revolutionary. It is patently clear from this single tablet alone that the deployment of these two supersyllabograms, exclusive of text, saves a considerable amount of precious space on what is ostensibly a very small tablet. That is the whole point. Given that most Linear B tablets are rarely wider than 15 $\mathrm{cm}$. (6 inches), is it any wonder that the Minoan/ Mycenaean scribes so frequently resorted to this ingenious stratagem, not only to save precious space on these tiny tablets, but to cram as much information into the narrow constraints the tablets 


\section{Knossos tablet KN 791 G c 101 \& the supersyllabograms KI \& O in sheep husbandry}

The actual tablet contains only 11 syllabograms.

K.791

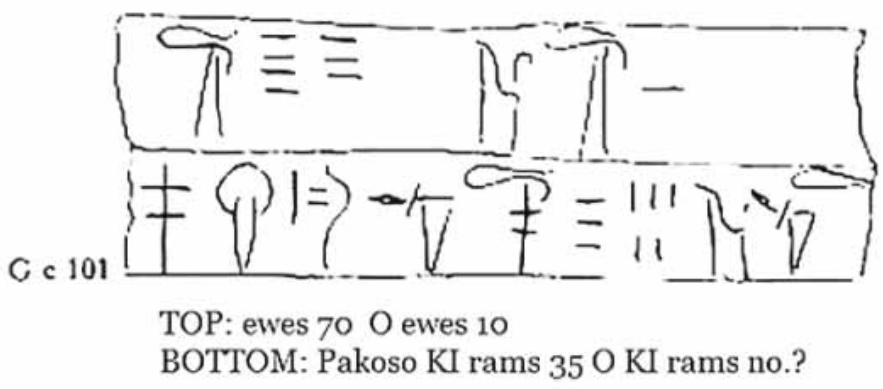

Translation (literal): All supersyllabograms are shorthand. ewes 70 usufruct lease field ewes 10

Sfakosos plot of land rams 35 lease field plot of land rams no.? Free translation:

70 ewes and 10 ewes in a usufruct lease field Sfakosos (is attending to) 35 rams on a plot of land and no.? of rams on a leased plot of land amounts to the same as the fictitious tablet, which uses 21 syllabograms to say the same thing!

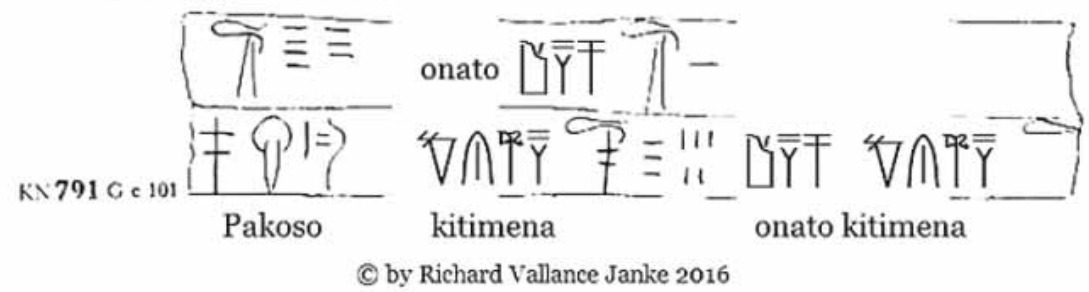

Fig. 3 - Introduction to Supersyllabograms.

imposed as they possibly could, without having to have recourse to a lot of cursive running text which would otherwise have cluttered them up?

You just have to take one glance at the difference in the space occupied by the actual tablet above, utilizing supersyllabograms almost exclusively, and the "same" imaginary tablet with the text spelled out in full. On the actual tablet, there are 11 syllabograms, inclusive of supersyllabograms, but exclusive of the numerics. In the case of the fictitious tablet, the number of syllabograms exclusive of supersyllabograms (because there are none), skyrockets to 21 , almost double the original (also exclusive of the numerics). You get the point. Certainly the Linear B scribes were bent on making a point of it, and with a vengeance. As a guild, both at Knossos, where supersyllabograms were in extensive use, and at Pylos, they were clearly conscious of the power of supersyllabo- grams, and resorted to them without compunction as often as they possibly could - which was very often indeed. The whole point is, and I must emphatically stress this: No-one deliberately resorts to any linguistic device when writing in any language, unless it serves a useful purpose beneficial to more effective communication, contextual or otherwise. And the linguistic device par excellence the Linear B scribes resorted to like clockwork, over and over, practically ad nauseam, is none other than the ubiquitous supersyllabogram.

But there is more to these mysterious supersyllabograms. The vast majority of supersyllabograms, heretofore tagged as dependent, are almost always configured in conjunction with any one of several pre-assigned ideograms in each of these sectors. The few rare exceptions, supersyllabograms not associated with any ideogram, are qualified as independent supersyllabograms. 


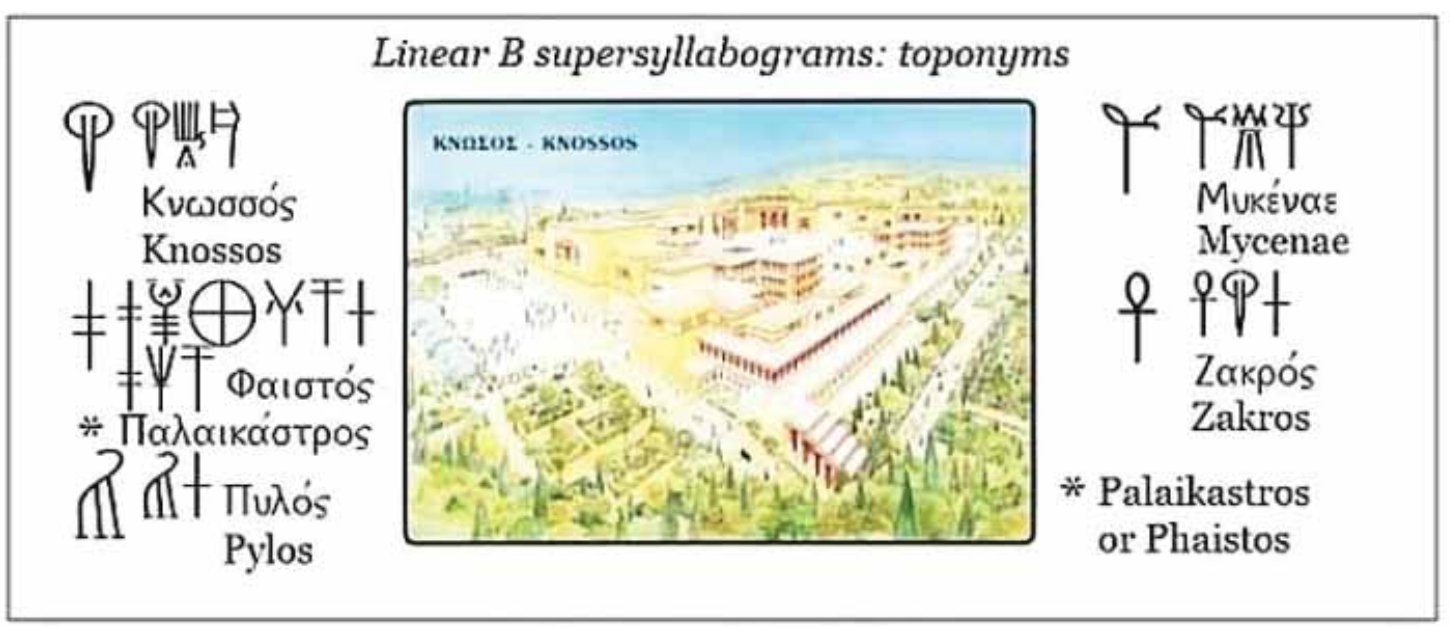

(c) by Richard Vallance Janke 2016

Table 1 - Linear B Supersyllabograms: Toponyms.

\section{Statistical Summary:}

From a statistically significant subset of 1146 fragments and tablets out of approximately 3,500 from Knossos, I recently extrapolated a total of 225 which sport supersyllabograms in every major sector of the Minoan/Mycenaean economy, these 225 accounting for fully $24 \%$ of every last fragment and tablet in the subset. As it turns out, in a syllabary of 61 syllabograms + one homophone (AI) for 62,36 or $59 \%$ are supersyllabograms. That is a staggering return for the scribes' deliberate and eminently practical investment in what is a remarkably clever stock technique to shortcut lengthy text, which would have otherwise simply cluttered up the very small Linear B tablets they routinely worked with. All this illustrates just how far the Linear B scribes were willing to go in swapping in supersyllabograms for text deliberately swapped out, replacing what would otherwise have been fictional tablets anywhere from 2 to 4 or even 5 times as long!

\section{The Path to Discovery:}

Although I had already translated scores of Linear B tablets by the winter of 2014, when I came across Prof. Thomas G. Palaima's excellent translation of Linear B Tablet Heidelburg HE Fl 1994, I hit upon something remarkable I had never before even noticed. Palaima, discerning that each city or settlement name was abbreviated to a single syllabogram, realized that each was the first syllabogram, i.e. the first syllable of their names in full, Konoso in Linear B or Knossos, Zakoro or Zakros, Paraikasatoro or Palaikastro (or possibly, Paito or Phaistos), Puro or Pylos and Mukene or Mycenae. These abbreviated codes for Minoan and Mycenaean cities and settlements uncannily mirror the two-character modern city codes symbolizing their international airports. This reveals something of the symbolic sophistication of the proto-historic syllabary, Mycenaean Linear B, taken to its limits. Table 1 identifies the five supersyllabograms KO, PA, PU, MU and ZA, each representing in turn the full names of the aforementioned Minoan/Mycenaean cities and settlements (Table 1).

In Mycenaean Linear B, out of a total of 36 supersyllabograms, while most of the rest of the supersyllabograms are typified as being dependent (see above), there exist only a few independent supersyllabograms, being these $5+$ two more in the textiles sector (for a total of 7). This excerpt from my presentation at the Pultusk Academy of the Humanities, July 1, 2015, provides a succinct overview of supersyllabograms: 
Linear $B$ tablet $K N 1232 E$ d 462: the code breaker The supersyllabogram PE definitely means "an enclosure"

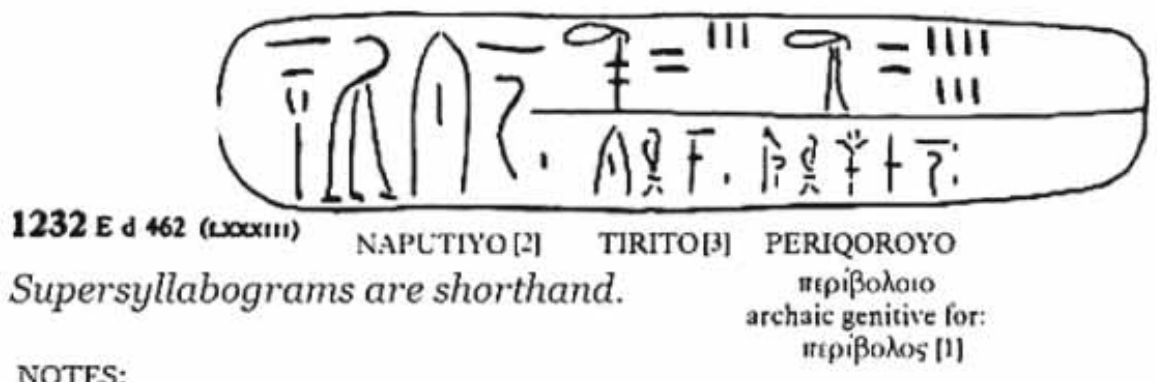

[1] Liddell \& Scott, 1986, pg. 547, mepißolos = enclosure (Attic), i.e. sheep pen, here =

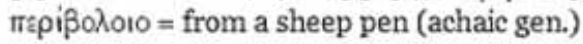

[2] Liddell \& Scott, pg. 457 vámn = woody dell or glen. Given the phenomenon of vowel glide over the centuries, Mycenaean NAPU could well be this word.

[3] Toponym, Tylinthos (Place of Stone).

Translation:

from sheep pens for 23 rams \& 27 ewes in a glen at Tylinthos.

NOTE: This critical tablet in sheep husbandry provides powerful circumstantial evidence for the actual meaning of the supersyllabogram PE. This is the only tablet in Linear B in which a supersyllabogram is spelled out in full. It confurms that supersyllabograms are exactly what the Mycenaean scribes meant them to be.

Translation of Linear B Tablet KN I:3: E d 46: $\mathrm{C}$ by Richard Vallance Janke :014

Fig. 4 - Linear B Tablet KN 1232 Ed 462: the code breaker.

Supersyllabograms are so information rich that they call for considerably more clarification, which is exactly what we intend to deliver. Careful examination of even a relatively small cross-section of tablets from Knossos alone confirms beyond a shadow of a doubt that this is the case.

On Knossos tablet KN SO 4439, we see the syllabogram ze post-charged onto the ideogram for "wheel". Checking it against Chris Tselentis' Linear B Lexicon, under the syllabogram ze, I found only one entry which fit the bill, the word zeukesi, the attested (A) dative plural for the derivative zeukos $(\mathrm{D}=$ derived or unattested nominative singular), meaning "a pair of" or "a team of'. This was almost too good to be true. I had discovered the exact word to suit the context, because this syllabogram, which is the first syllable of the word zeukos in both dictionaries, is paired with the ideogram for a chariot wheel. So the syllabogram ze is yet again the first syllable of the Mycenaean
Linear B word or phrase it symbolizes.

The next supersyllabogram, mo is the first syllable of mono = "a single" or "one only" or even "a spare". The translation, "a set of chariot wheels on axle and a spare one, made from a willow tree" leaps to the fore. Still, since I had no collaborative empirical evidence that the translation was correct, even though it made perfect sense, I could only surmise that this was a standard scribal practice. Was there any real proof that there was any substance to the use of supersyllabograms, or even better, that scribal use of them was persistent?

I was about to be richly rewarded. I hit upon that rarity of rarities, the "magic bullet" on Knossos tablet KN 1232 Ed 462, which spells out the word periqoro, meaning "an enclosure", in other words "a sheep pen" immediately adjacent to the ideogram for "ram", viz. (Fig. 4):

The very next tablet, KN 1233 En 224 replaces the word periqoro $=$ "an enclosure" with 
the syllabogram PE, the first syllable of the very same word, again locked in with the ideogram for "ram". Thanks to an obliging ancient scribe, I had adventitiously broken the code. Hard on the heels of these two eye-popping tablets, a whole string of them with the supersyllabogram PE sprang to the fore (inside the range of KN 1223 En 223 to KN 1360 En 225). The code had been cracked wide open. The time had finally come for me to be able to isolate, identify, define and classify once and for all the phenomenon of the supersyllabogram, if possible across every single sector of the Minoan/Mycenaean economy. If only the scribes resorted to this practice not on just a few scattered tablets, but on hundreds of them, I would have proof positive. As it fortuitously turns out, they did, and with a vengeance.

Moving right on then, we now proceed to examine in minute detail every single supersyllabogram in all the major sectors of the Minoan/Mycenaean economy, starting with the military sector, followed by the vessels and pottery, then by the textiles and finally by the agricultural sector.

The determination of the polysemiotic accuracy of supersyllabograms in Mycenaean Linear B:

One of the greatest problems besetting an adequate decipherment of any Linear B tablet is the proper determination of the meanings of each and every character on it. In the case of supersyllabograms, this all boils down to a question of (poly) semiotics. Are there any discriminative criteria we may apply to the accurate decipherment of supersyllabograms, insofar as that is possible? Definitively yes. These are:

Criterion 1: The establishment and strict application of a scalar weighting system to supersyllabograms clearly identified on Linear B tablets, as follows: $1=$ improbable, $2=$ possible, $3=$ (highly) probable and $4=$ definite.

Supersyllabograms must of necessity be tagged with a numeric weight commensurate with the likelihood that there exists a major (never minor) Linear B economic term equivalent to it. We can establish the weighting scale as follows:
$1=$ a supersyllabogram for which there exists no term in the lexicon of the Linear B vocabulary attributed anywhere on any extant tablet(s), but rather for which a term must be derived by an expert philologist. The primary problem with this consists in the fact that the etymological roots of so many archaic and anachronistic Mycenaean Greek words are irretrievably lost and beyond our reach, either because they fell into disuse with the collapse of the Mycenaean Empire ca. 1200 BCE or because, even though they survived beyond 1200 BCE, they only did so in very small numbers and almost always in the Homeric lexicon only, beyond which such terminology fell out of the lexical repertoire forever in all of the subsequent ancient East Greek dialects. Thus, the etymological roots of such Mycenaean terms is at best very doubtful, and at worst impossible to confirm.

The fact that the meanings of almost all of the supersyllabograms at a scalar weight of 1 are irretrievably lost does not in the least invalidate supersyllabograms per se, since they are a subset of the Linear B words which they symbolize. If then the words they replace are included in the Linear B lexicon - and they are - then by the same token, so must their equivalent SSYLS. Moreover, there are also plenty of other terms in Linear B at level 1 for which there are no supersyllabograms, and so what is good for them is good for supersyllabograms at the same level. Just because we cannot recover the meanings of so many of the words at level 1 does not signify that they are not Mycenaean Greek, or at the very least of proto-Indo-European origin, or that a few of them may possibly even be Minoan. It is a commonplace phenomenon that any language, ancient or modern, inherits at least a few words from previous languages, even if the latter are in no way related to the former, as apparently Minoan and Mycenaean Greek are. Indeed, if we take the example of English, we find that thousands and thousands of words prior to English are incorporated into the Lexicon. This is especially true of medieval Norman French, of which there are at least 100,000 

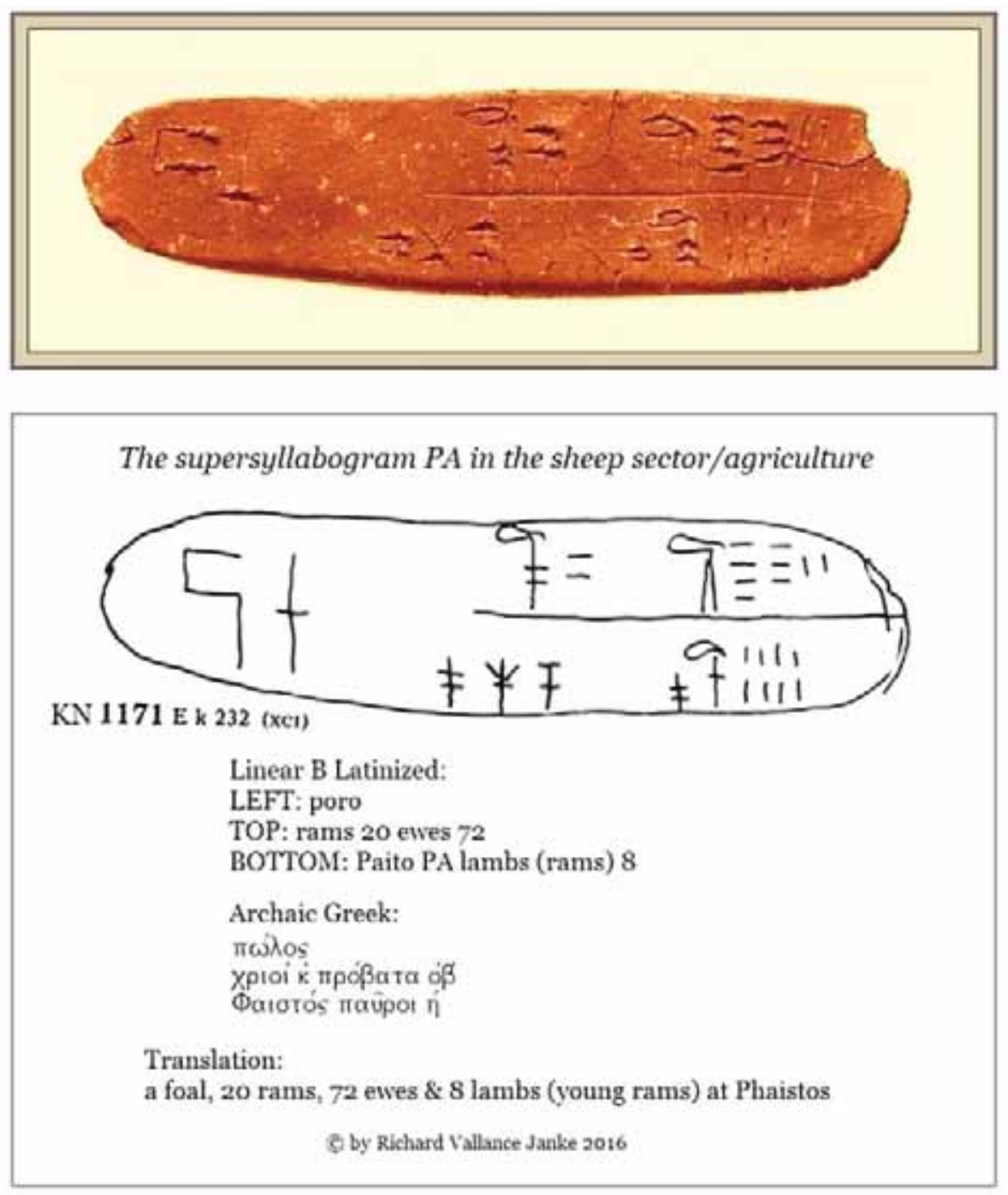

Fig. 5 - Linear B tablet KN 1171 E k 232, The supersyllabogram PA in sheep husbandry.

words in English. So what is good for one language is good for another, ancient or modern. Although the importation of non-Mycenaean terms into Mycenaean Greek may be minimal, it is not non-existent. For instance, we find in Mycenaean the words serino = celery and sasama = sesame, neither of which are Greek at all. A supersyllabograms is a single syllabogram subset of consecutive syllabograms comprising Mycenaean words.

There are so many archaic Mycenaean Greek words at level 1 , a considerable number of which are the counterparts to the supersyllabograms which symbolize them, that it would be rash to assume that we have any accurate account of what these terms actually mean. Such supersyl- labograms are said to correspond to improbable terminological equivalents. They are by semiotic account quite unverifiable. There are, however, some instances where it can be established that there may potentially exist a derived term corresponding to the supersyllabogram which supposedly symbolizes it. In such cases, the scalar weight is cautiously raised to a value of 2 . One exemplary instance of this phenomenon is attested in 38 Linear B tablets in the sheep husbandry sub-sector of the agricultural sector (Fig. 5).

Although the supersyllabogram PA occurs scores of times on Linear B tablets in the sheep husbandry sub-sector of the agricultural sector of the Minoan/Mycenaean economy, there un- 
fortunately exists no attributed Linear B term to which this supersyllabogram can conceivably correspond. This poses a serious problem. It is obvious that the supersyllabogram PA meant a very great deal to the Linear B scribes. Otherwise they would not have resorted to it so often (on some 38 tablets, mostly in the KN 1200-1300 and KN 1500-1600 range). But what on earth can it possibly mean? To the rescue the Pocket Oxford Classical Greek Dictionary (Morwood and Taylor: 250). The problem inherent to this approach, i.e. reliance on a classical Greek dictionary diachronically centuries posterior to the disappearance of the Mycenaean dialect ca. 1200 BCE is that it assumes that the Mycenaean Linear B term corresponding to the supersyllabogram (in this case PA) was not archaic by the time of the advent of the earliest avatars of the Greek alphabet (ca. 900$800 \mathrm{BCE}$ ), but that it survived at least until the Homeric era. Nonetheless, there exists in Classical Attic Greek a term which fits the context like a glove, and this is the word pauro maûpos = very small or little, which in turn corresponds to the same word in Latin, parvus = little. But what is "very small" supposed to refer to? Given that the scores of tablets on which this supersyllabogram occurs all deal with sheep without exception, we may assume with reasonable confidence that the scribes are referring to "small sheep", in other words "lambs". But once again the caveat: there is absolutely no way of our telling whether or not the term is commensurate with the supersyllabogram. So we are going out on a limb here. On the other hand, the word "lamb" fits the context so well that it certainly should be considered as a potentially viable candidate. For more on this, see Criterion 2 below.

$2=$ a supersyllabogram for which there exists one instance or rarely two or three for a term corresponding to that supersyllabogram. This scenario is scarcely much of an improvement on a scalar value of 1 , but it is better than nothing. A term correspondent to a supersyllabogram at this level often entails a necessary differentiation between supersyllabograms for which there exist comparable attributed terms on one or perhaps 2 or 3 tablets, and on the other hand derived terminology for which there exists no equivalent terminology on any Linear B tablet at level 1 above. Supersyllabograms at level 2 are construed as referring to a comparable Linear B word which may possibly have existed.

$3=$ a supersyllabogram which is susceptible to the application of a sound methodology for the determination of its accuracy in the context of a methodological cross-contextual comparison of the attributable (poly)semiotic values of any given supersyllabogram over a wide range of tablets, the more the better. Such supersyllabograms are said to be probable or even highly probable, and there are plenty of these, as we see for instance with this tablet (Fig. 6).

The supersyllabogram PU in the textiles sector, which occurs on something like 20 tablets, refers to a type of textile or cloth, called pukateriya $\phi \mathrm{u}^{-}$

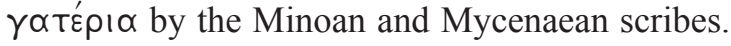
Unfortunately, this Mycenaean Greek word is archaic, appearing nowhere in any East Greek dialect diachronically posterior to Mycenaean Greek. But in this case, contrary to what one might expect, this does not mean that we at least do not know that this is definitely some type of cloth, because, along with several other types of textiles in Mycenaean Greek, all of which are also archaic and all of which appear on scores and scores of Linear B tablets in the textiles sector, it is incontestable that this is a type of cloth. Why? - because this supersyllabogram is attributive, with PU appearing inside the ideogram, as is invariably the case with all attributive supersyllabograms in any sector of the Minoan/Mycenaean economy. By attributive we mean that the supersyllabogram, in this case $\mathrm{PU}$, is in fact an actual attribute of the ideogram in which it is incharged. In other words, since the blank ideogram definitively means "textiles", the supersyllabogram must be an attribute of a textile, circumscribing it adjectivally. We shall encounter plenty more incharged supersyllabograms, not 


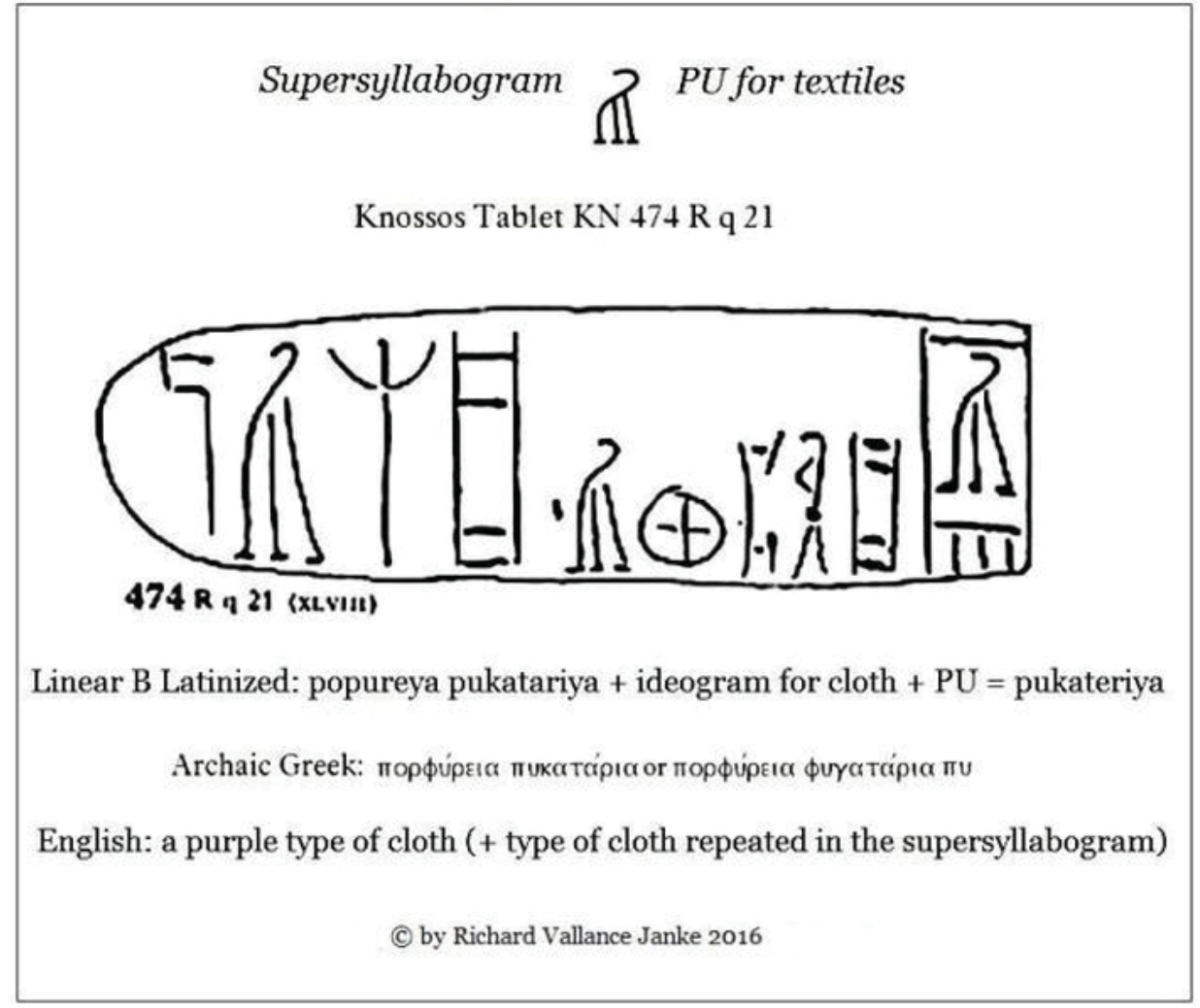

Fig. 6 - Knossos tablet KN 474 R 1 21, the supersyllabogram PU in the textiles sector.

only in the textiles, but in the vessels and pottery and in the military sectors as well (but never in the agricultural sector).

$4=$ a supersyllabogram for which there exists a commensurate Linear B term on several or a great many tablets, which cannot conceivably be in any doubt. These terms, actualized on numerous tablets, are said to be rooted in the real life world of each of the 4 major sectors of the Minoan/Mycenaean economy. Such supersyllabograms are invariably tagged as definite and incontestable. They include $\mathrm{KI}$ and $\mathrm{O}$ in the sheep husbandry sub-sector of the agricultural sector of the Minoan/Mycenaean economy, for which there can be no doubt whatsoever attached to their meaning. $\mathrm{KI}=$ kitimena $=\mathrm{a}$ plot of land, and $\mathrm{O}$ onato $=\mathrm{a}$ lease field. For an actual demonstration of the inviolability of such supersyllabograms, please refer back to Fig. 3.

Criterion 2: This is the rigorous application of the incontestable principle that the Linear $\mathrm{B}$ scribes always resorted to specific determinative terminology equivalent to a supersyllabogram which was invariably descriptive of a major, never a minor, aspect of the métiers, activities, commodities and end-products intrinsically proper to any of the four primary sectors of the Minoan/Mycenaean economy, be it the military, vessels and pottery, textiles or the agricultural sector. While this is far and away the paramount consideration to be taken into account in the determination of accurate terminology of Linear B vocabulary commensurate with the polysemiotic values of each supersyllabogram, this does not in least preclude the concomitant application of Criterion 1, which must unfailingly be considered in tandem with Criterion 2.

Supersyllabograms in the military sector of the Minoan/Mycenaean economy:

All in all, there are 15 supersyllabograms in the military sector of the Minoan/Mycenaean economy. The Table of Supersyllabograms in the 


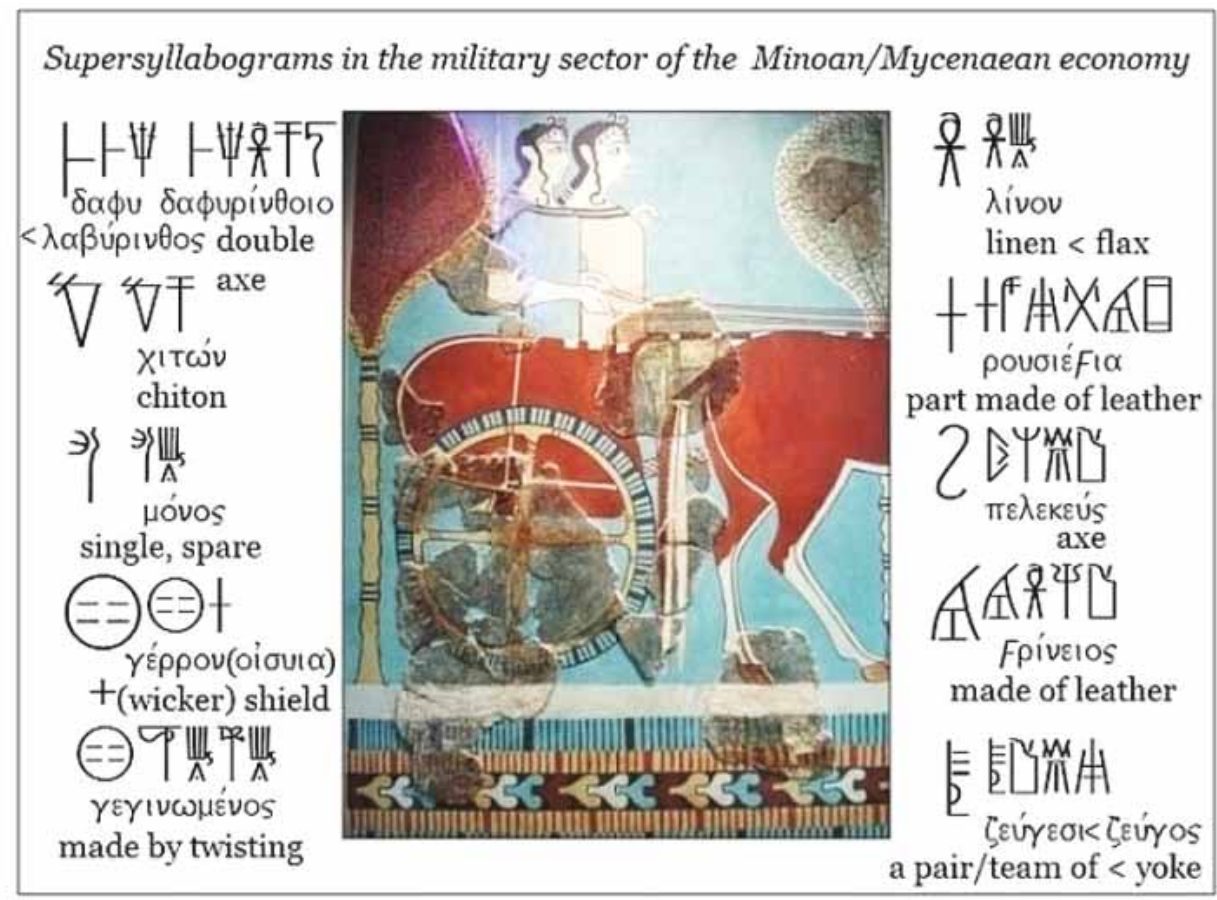

Examples of supersyllabograms with their ideograms

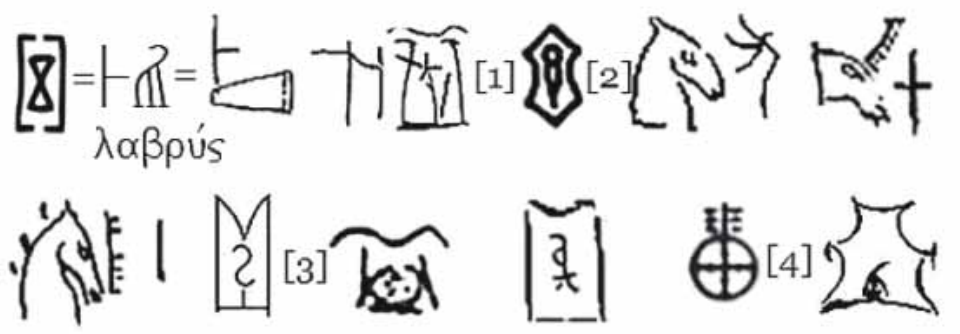

Special notes:

[1] combination of the associative SSYL O and the attributive $\mathrm{KI}$

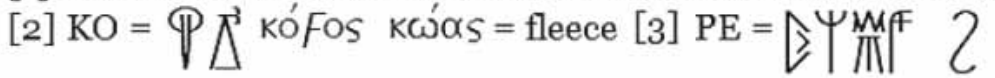

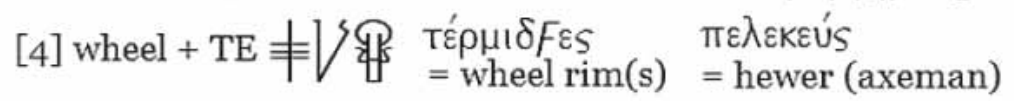

(C) by Richard Vallance Janke 2016

Table 2 - Supersyllabograms in the military sector of the Minoan/Mycenaean economy.

military sector of the Minoan/Mycenaean economy, lists the 10 most frequently used, as illustrated here in Table 2.

Assigning scalar weights to the supersyllabograms in this chart, we have: DA dapu

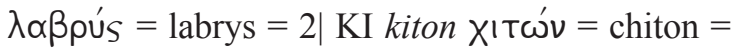

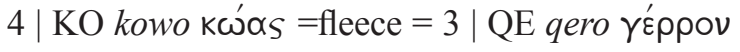

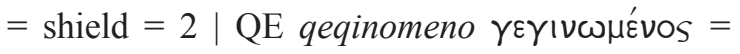
made by twisting $=2 \mid$ RI rino $\lambda^{\prime}$ vov $=$ linen $=4 \mid$

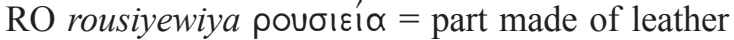
$=2 \mid$ WE perekeu $\pi \varepsilon \lambda \varepsilon \kappa \varepsilon u ́ S=$ hewer $($ axeman $)=$ 2/3 | WI wirineo Фpíveos = made of leather $=4$

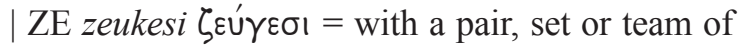
$=4 \mid \mathrm{TE}$ temidwe $=\mathrm{T}^{\mathrm{s}} \mathrm{\rho} \mu \mathrm{I} \delta \Phi_{\varepsilon S}=($ wheel $) \operatorname{rim}(\mathrm{s})$ $($ derived $<$ - circumference $)=3$. These weights determine the reliability of the terms to which I have assigned the supersyllabograms, where $1=$ least and $4=$ most reliable. 
Two points of particular note. The attributive SSYL KI kito = chiton, with a weight of 4 is exceptionally used in conjunction with the associative supersyllabogram $\mathrm{O}$, which in this context = opero ${ }^{`}$ wopk (or "debt/liability or asset"), in other words a tailor "is working on a linen undergarment or tunic for armour, which is an asset". The SSYL WE is equivalent to perekeu = hewer (axeman). This is highly unusual, and is the sole instance in all the Linear B supersyllabograms where the SSYL WE does not correspond to the Linear B word which it symbolizes, i.e. perekeu. Nevertheless, I feel relatively confident of this meaning. This assumption is of course wide open to academic dispute.

[* Once I have assigned the Greek equivalent for any Linear B word, I do not repeat it for the same word again.]

Associative versus Attributive Supersyllabograms:

At this point that we are called upon to draw the marked distinction between associative (as) and attributive (at) supersyllabograms, since both types figure prominently in the military sector. All syllabograms in Mycenaean Linear B, without exception, appear either (a) adjacent to the ideogram or (b) inside the ideogram they qualify, and (c) they repeat themselves over and over, like clockwork. Supersyllabograms which appear adjacent to their ideograms are invariably associative (as), while those which appear inside their ideograms are invariably attributive (at). Associative supersyllabograms, which appear primarily and in droves in the agricultural sectors of the Minoan-Mycenaean economy, are either surcharged, appearing to top right or occasionally to the top left, supercharged, appearing right on top of the ideogram they qualify or pre-charged or post-charged (far more often than sur/supercharged). Attributive supersyllabograms are invariably incharged, bound inside the ideogram they qualify. The distinction neatly summarizes the marked difference between associative (as) syllabograms, which account for all of the SSYLS in the agricultural sector, and attributive (at) supersyllabograms, which appear primarily in the textiles and vessels (pottery, amphorae, cups etc.) sectors of the Late Minoan III and Mycenaean economies.

\section{Associative Supersyllabograms:}

Associative (as) dependent supersyllabograms inform us of some physical real-world element, usually in the agricultural sector, often a land tenure factor, which relates to the ideogram itself, or which circumscribes its environment, especially in the livestock raising sub-sector, but which does not define the ideogram itself in any way. As we have already seen in Fig. 3, the ideogram for "ram" coupled with the number of rams accounted for in this inventory, the supersyllabogram KI informs us that these rams are being raised on a

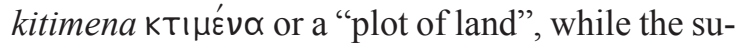
persyllabogram O with the ideogram for "sheep" informs us that the sheep are being raised on an onato óvatov or "a lease(d) field", actually "a usufruct field leased by an overseer to a tenant". That is a great deal of text to cram into one syllabogram and one ideogram. The scribe could have simply stated that $\mathrm{x}$ no. of sheep were being raised, and left it at that, without recourse to supersyllabograms. But he did not. Optionally but intentionally conjoining just one supersyllabogram (KI or O) with the ideogram for "sheep" or "rams", the scribe has effectively telescoped what would otherwise have been discursive descriptive text. In other words, these two supersyllabograms in and of themselves are very precise, information-rich semiotic symbols of the descriptive text they so neatly replace.

The associative supersyllabogram sets the ideogram, which all alone would simply mean "sheep" "rams" or "ewes" in a highly specific context. But, since they are utterly meaningless unless immediately adjacent to the ideogram they qualify, single syllabograms in this class are never used unless strictly paired with an ideogram. While the syl- 
labogram KI must mean "a plot of land" when associated with any of the three ideograms for sheep, strip away that ideogram, and KI all by itself could be the first syllable of any one of no fewer than 175 entries under KI in Chris Tselentis' Linear B Lexicon. Utterly meaningless without context with the appropriate linked ideogram.

In the military sector of the Minoan/Mycenaean economy, with only 2 of them all told, $\mathrm{MO}=$ mono $=$ single -or- spare (wheel) and $\mathrm{ZE}=z e u$ gesi $=$ with a pair of, with a team of (horses) or with (a set of) wheels on axle, associative supersyllabograms are distinctly in the minority. It is absolutely essential to understand at this point the powerful impact of the all-pervasive formulaic language on Linear B tablets in all sectors of the economy. While the Linear B vocabulary is formulaic, supersyllabograms are to the extreme.

\section{Attributive Supersyllabograms:}

Attributive (at) dependent supersyllabograms always appear inside the ideogram which they qualify, never adjacent to it. They always describe an actual attribute of the ideogram. Neither the supersyllabogram nor the ideogram can exist without the other being present, if one is to make any sense at all of what the two, once married, can possibly mean. They are intrinsically symbiotic. In the military sector of the Minoan/Mycenaean economy, attributive supersyllabograms figure far more prominently than associative, there being a total of 10 major ones in Table 2, as opposed to 2 associative supersyllabograms.

For instance, the syllabogram RI inside the ideogram is the first syllabogram, i.e. the first syllable of the Mycenaean word for rino = linen. Neither type of dependent supersyllabogram, associative (as) or attributive (at), was ever even noticed, let alone systematically isolated and tabulated in Mycenaean Linear B until I took it upon myself to do just that from 2014-2016.

The artificiality of Mycenaean Linear B as a construct:

It is of critical importance for us to realize in the twenty-first century, so extremely far removed from the Minoan/Mycenaean world, with its own peculiar economic superstructure/infrastructure of some 3,500 to 3,200 years ago, that the way we conceptualize language, and by this I mean the lexical function of natural vocabulary in particular, is so alien to the manner in which the Linear B scribes visualized it (language) that it takes the utmost effort on our part as modern philologists not to inject our ingrained and to some extent unconscious prejudices into the system which the Linear B scribes so ingeniously invented for the purposes of accounting and inventory keeping alone within the strict confines of the structure of the Minoan/ Mycenaean palatial administration. While present day lexicologists in all modern languages are almost exclusively concerned with both the literary and natural colloquial language, especially the latter, nothing could be further from the truth when it comes to Mycenaean Greek. Mycenaean Greek as attested in the corpus of Linear B tablets alone, regardless of provenance (Knossos, Pylos, Mycenae, Thebes etc.) never was reflective of any "literary" language, simply because there was none, nor with spoken Mycenaean, though we can be certain that the latter contained a much larger vocabulary than is attested on the tablets.

But if the tablets are not concerned with the natural Mycenaean language, what "language" do they reflect? In short, they do not reflect the Mycenaean language in its broadest sense as a natural language at all. They, the tablets, are a highly restricted subset of Mycenaean Greek, which is concerned solely with inventory keeping and accounting, and nothing else whatsoever. This is the precise reason why there is no dialectical variance across tablets of different provenance (Knossos, Pylos etc.). Accounting and inventorial language is just that, and nothing more. Allowing for and more to the point, even permitting or tolerating variations in accounting and inventory terminology, was out of the question then as now in modern 
inventories, regardless of the language in which such inventories ever were or are still compiled. To draw a parallel which neatly illustrates my point, take the terminology of the computer and online world. Even though it has nothing to do with accounting, it too is formulaic. So if this is true for the vocabulary in highly specialized areas of modern vocabulary, regardless of language, how much more so must it be for Mycenaean Greek.

We must bear uppermost in mind this vital distinction between natural and technical language at all times, for failure to do so warps the Mycenaean Linear B lexicon beyond recognition and plausibility. Why so? - because, and I insist on emphatically repeating, all vocabulary in Mycenaean Greek is formulaic to the extreme, as that is what one would naturally expect of inventories and accounts. But of all the lexical phenomena in Mycenaean Linear B, it is the supersyllabograms which are the most radically formulaic, because they constitutionally must be. Extreme formalism is intrinsic to their very nature. A supersyllabogram never varies, whether it is associative or attributive. What does this imply? A very great deal.

For instance, while it would appear at first sight that the two associative supersyllabograms in the military sector, $\mathrm{MO}=$ mono $=$ single, a spare, and $\mathrm{ZE}=$ zeugesi $=$ with a pair of, mean that and nothing more, this is simply not the case. Given that supersyllabograms are intrinsically formulaic in the extreme, because they are in effect fossilized, the same supersyllabograms, in this case, $\mathrm{MO}$ and ZE must be used over and over in the context of and in conjunction with (radically) different ideograms, with a particular emphasis on the highly variable connotations of these ideograms.

What do you imagine the Mycenaean Linear B scribes actually meant when they paired the SSYL (supersyllabogram) ZE with the ideogram for "horse" or with that for "wheels"?

Although the supersyllabogram ZE is formulaic and fossilized, this does not in the least mean that the scribes were not aware of the critical distinctions between pairing for instance ZE (osten- sibly meaning just "a pair of") with horses on the one hand, and chariot wheels on the other. They knew exactly what IQO (horse) + ZE meant and what wheel + ZE meant. What they clearly intended ZE to mean, and what it actually meant to them when post-charged with IQO = horses is "a team of horses", not simply just a pair of horses. On the other hand, when it comes to "a pair of wheels", it does not take much imagination to realize that what the scribes intended the supersyllabogram to mean was not simply a pair of wheels, but "a set of wheels on axle" or better yet, simply "wheels on axle", since after all that is precisely what they were, the wheels of chariots on axle. In other words, while the supersyllabogram per se (in this case ZE) is formulaic and fossilized, its lexicographic meaning is not. It is polysemiotic, exemplifying the principle that when the scribes changed the specific context of the ideogram with which the supersyllabogram, regardless, was paired, they inevitably and automatically changed its fundamental meaning. This distinction is critical, for it allows us to peer straight through the apparently suffocating confines of fossilized supersyllabograms into the actual meaning of each supersyllabogram in various contexts in the collegial mindset of the scribes as a guild. They knew exactly what each supersyllabogram meant, even if it was the same one in (slightly) different contexts and even if in the same economic sector, because each supersyllabogram was meant to precisely, never vaguely, symbolize a particular major economic indicator.

Allow me to elucidate further. Take the supersyllabogram $\mathrm{MO}=$ "one" or "single" used in conjunction with the ideogram for "wheel". It just so happens that almost all Linear B tablets concerned with the manufacture of wheels in chariot construction not only assign the post-charged SSYL ZE to specify wheels on axle, but by the same token account for the pre-charged $\mathrm{MO}+$ wheel. If then wheels + ZE means wheels on axle, it reasonably follows that $\mathrm{MO}+$ wheel or wheels does not simply refer to "a single wheel". Other- 
wise, how on earth could it be that a single wheel is a single wheel many times over? But you cannot tout one single wheel as being one and one only, when, more often than not, there are several "spare wheels" for the same number of sets of wheels on axle. Tablets which list $\mathrm{n}$ number of sets of wheels on axle, where $\mathrm{n}>1$, almost always list the same number of spare wheels for each set of wheels on axle. Now we must be careful to make the distinction between the fact that a set of wheels on axle means a pair of wheels, in other words, 2 of them, and the fact that for each set of wheels (2 wheels), there is only 1 spare wheel. Although there are 2 wheels on axle in a set, there is only $\mathbf{1}$ set, hence the correlation between the set and the spare is 1 to 1 . As in present-day car manufacturing, the Mycenaean chariot builders always included a spare wheel just in case. Makes perfect sense.

Now for a completely different example, this time with reference to the attributive supersyllabogram QE. When QE qeqinomeno is incharged in the ideogram for armour, it means "made by twisting", probably with reference to intertwining small armoured chains by crisscrossing. On the other hand, when QE is incharged inside the ideogram for a shield, it probably means

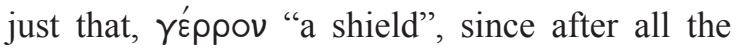
syllabogram QE by itself, without the little handle to the top left, is otherwise a simple syllabogram which means nothing unless part of a Linear B word. Refer back to Figure 2 above.

There remains one more particularly bizarre concatenation of not one, but two supersyllabograms, both bound with the same ideogram. This is the one and only instance in the entire repertoire of Linear tablets where such a phenomenon occurs. These I refer to as the composite supersyllabograms E \& KO (Fig. 7):

The text and translation are pretty much self-explanatory. But what is truly tantalizing about this particular tablet is that, by cramming two supersyllabograms together with one ideogram IQO = horse, it manages to convey so much information, but with far fewer syllabograms than if the tablet had been written out in full... which it wasn't, for the obvious reason that the scribe simply could not be bothered wasting what was ostensibly precious space on such a tiny tablet. This brings us to the next defining characteristic of supersyllabograms, be they associative or attributive. Supersyllabograms, though formulaic in the extreme and fossilized, are information rich. A single supersyllabogram coupled with an ideogram can replace a lot of what would have otherwise been totally needless discursive text. But 2 supersyllabograms paired with one ideogram carry this feature to even further extremes. If this is not a linguistic practice for which there is no equivalent in any language, ancient or modern, I do not know what is. And the fact that the Linear B scribes consciously and deliberately resorted to this stratagem over and over, hundreds of times $(800+)$, makes it crystal clear that this was (and is) a linguistic device unlike any other ever seen before or since Mycenaean Linear B. That this fully standardized and formulaic practice on the part of the scribes was a brilliant stratagem goes without saying.

In the end it does not matter one jot whether we, in the twenty-first century, find this stratagem counter-intuitive. My point, the very same I made in my presentation, "The Rôle of Supersyllabograms in Mycenaean Greek" at The Third Interdisciplinary Conference, "Thinking Symbols", July 1 2015, at the Pultusk Academy of the Humanities, simply is this, and I quote:

They (supersyllabograms) are there because the scribes, as a guild, all understood perfectly well that each and every supersyllabogram always meant one thing and one thing only to them in its proper context (context being variable). The very notion of future interpretations of what was obvious to them as accountants would have never entered their minds. But we owe it to ourselves to decipher as many supersyllabograms as we can. Otherwise we learn nothing new of value to the field of historical linguistics in Mycenaean Linear B ... passim ... To summarize, Mycenaean Greek texts in Linear B are formulaic on at least 


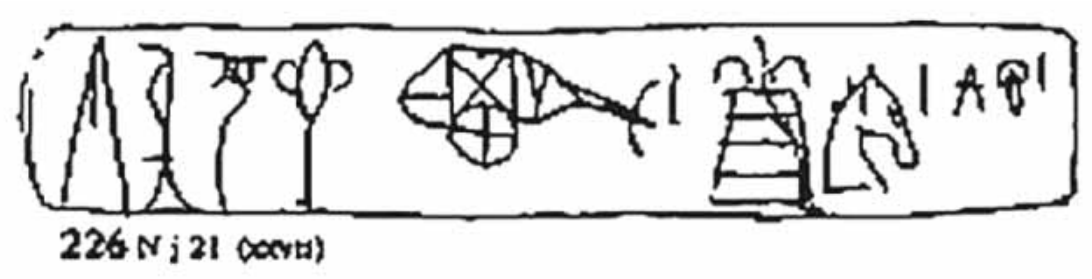

This is the one and only tablet in Linear B on which two supersyllabograms appear with the ideogram they modify. But why 2 ? ... \& why are they flanked by the numeric for "1" in Linear B? See this post for the most credible explanation. The supersyllabogram $A$ E probably means AAtキF $\Leftrightarrow \Psi=$ eeropayoqene = a part of the harness, possibly

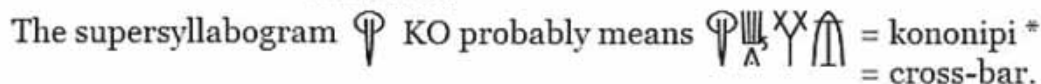
kononipi ${ }^{*}$ in (archaic) Greek $=$ kovovi $\delta ı \mid$ ।.

Literal translation:

Tirisoka + ideogam for chariot 1 + ideogram for armour + ideogram for horse $1+$ supersyllabograms E \& $\mathrm{KO} 1$

Free translation:

1 chariot for the hunt with an armoured driver, with a part of the harness (bridle?) and a cross-bar for the horses. ${ }^{* *}$

OR (much more likely) Thrisokas' chariot with him in armour, and with a part of the harness (bridle?) and a cross-bar for the horses. ${ }^{* *}$

** The supersyllabograms E \& KO bracketed by 1 on the left side \& 1 on the right appear to refer to 2 horses, which is what we would expect for a Bronze Age Mycenaean chariot.

\section{(C) by Richard Vallance Janke 2016}

Fig. 7 - The composite supersyllabograms E \& KO with the ideogram IQO = horse.

three counts: Mycenaean text on extant tablets is routinely formulaic to the extreme. Mycenaean ideograms are likewise formulaic in all instances, completely standardized ... passim... Supersyllabograms, which are rampant on extant tablets from Knossos, appearing on some 800 out of 3,500 relatively intact tablets (exclusive of fragments), are also invariably standardized.

To round out our observations on supersyllabograms in the military sector, here you see Linear B tablets KN 04.38 and 04.39 , which demonstrate the use of the supersyllabogram ZE in conjunction with wheels (Fig. 8):

We can see that the ideogram for wheel $+\mathrm{ZE}$ represents "(a set of) wheels on axle", whereas the supersyllabogram MO preceding the ideogram for wheel stands for a "spare wheel". You will note that, with these two tablets, as with practically all others, I display the text not only in Latinized Linear B, but in (archaic) Greek and English as well. ${ }^{5}$

Supersyllabograms in the pottery and vessels sector of the Minoan/Mycenaean economy:

Here we have the Table of Supersyllabograms in the pottery and vessels sector of the Minoan/

5 In the text of this article, with the exception of the Figures and Tables, all references to supersyllabograms and words in Linear B are Latinized, in accordance with L. R. Palmer's practice in The Interpretation of Mycenaean Greek Texts (1963). 

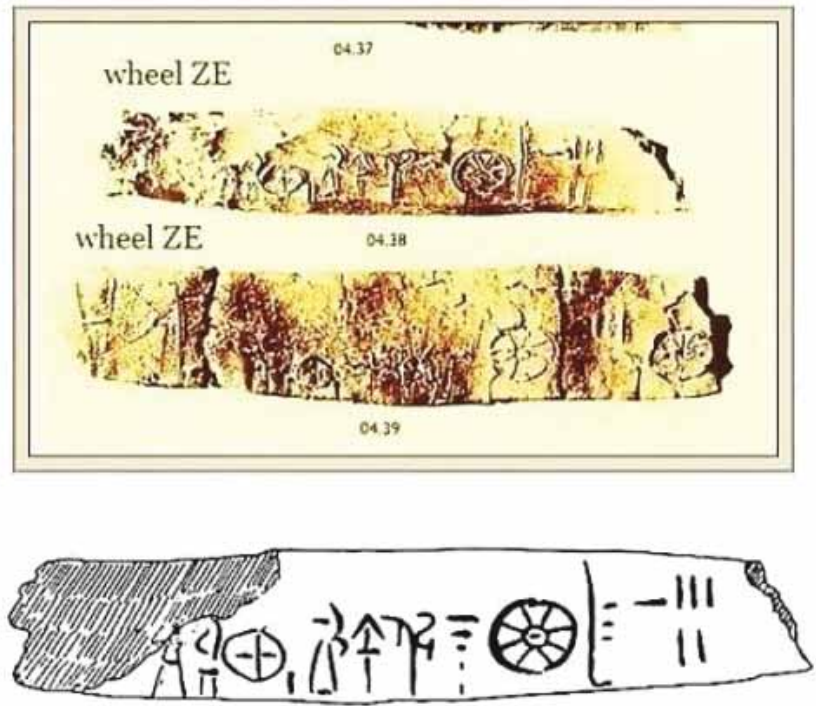

$04-38 \mathrm{~N}$ u 11

Linear B Latinized:

erika wozomena wheel ZE 15

Archaic Greek:

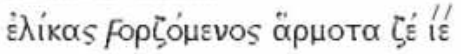

Translation:

15 well-constructed wheels of willow on axle

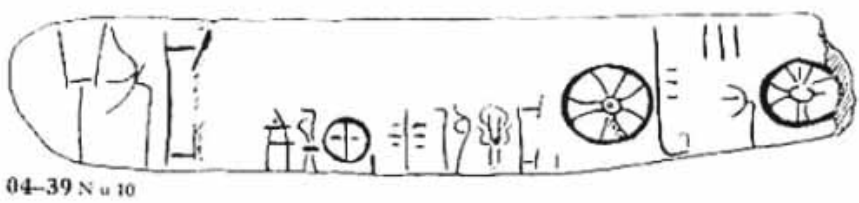

Linear B Latinized: Supersyllabograms are shorthand. amota erika temidweta amota $\mathrm{ZE} 3$ mono amota Archaic Greek:

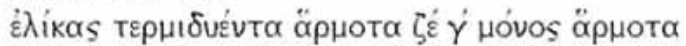

Translation:

wheels: wheel rims made of willow, 3 wheels on axle \& one spare wheel

(C) by Richard Vallance Janke 2016

Fig. 8 - Knossos Tablets K 04.38 \& 04.39. Military

Mycenaean economy (Table 3).

Assigning scalar weights to the supersyllabograms in this chart, we have: A aporewe $=\alpha 0 \mu(\varphi \mathrm{\imath})$

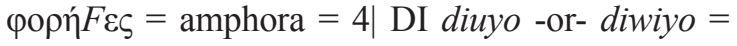

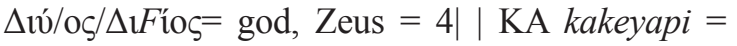
$\chi \alpha \lambda \kappa \varepsilon i / \alpha \varphi \mathrm{l}=$ with copper $=4 \mid \mathrm{NE}$ newa/newo $=$

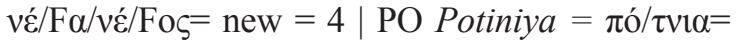
Potnia $=2 / 3 \mid$ SA linon $=3 \mid$ SO soro $=$ бopós $=$

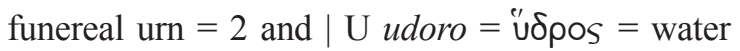

flask $=4$. We have had to assign the value of 2 or 3 to PO Potiniya $=$ (the goddess) Potnia because it is uncertain whether or not PO actually refers to her and not to someone or something else. For more on this conundrum, see "An Archaeologist's Translation of Pylos Tablet TA 641-1952 (Ventris), with an Introduction to Supersyllabograms in the Vessels and Pottery Sector in Mycenaean Linear B", pp. 133-161 in Archaeology and Science, ISSN 14527448, 10 (2014), in which I introduce and discuss 


\section{Table 3}

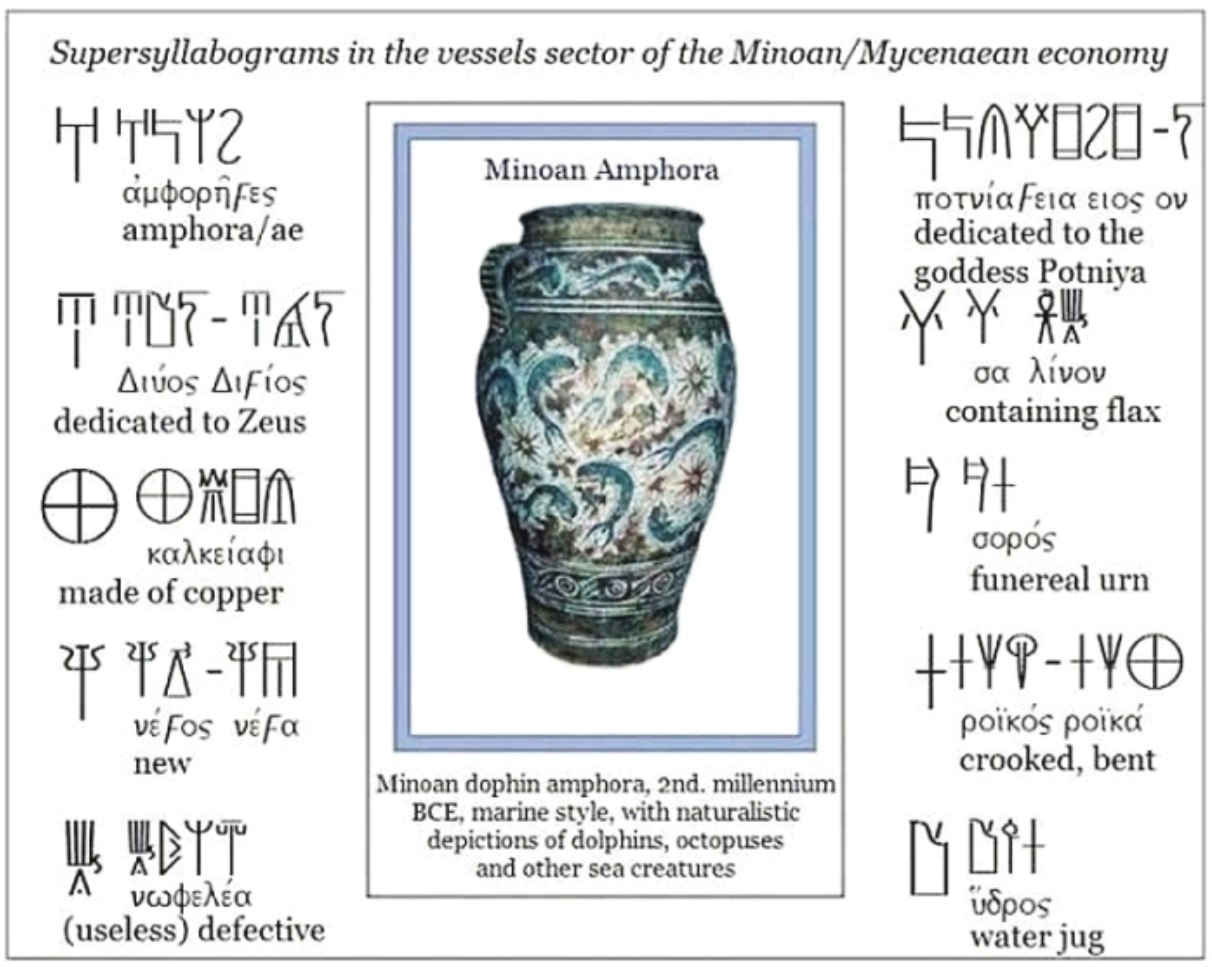

(C) by Richard Vallance Janke 2016

Examples of supersyllabograms in the vessels/pottery sector

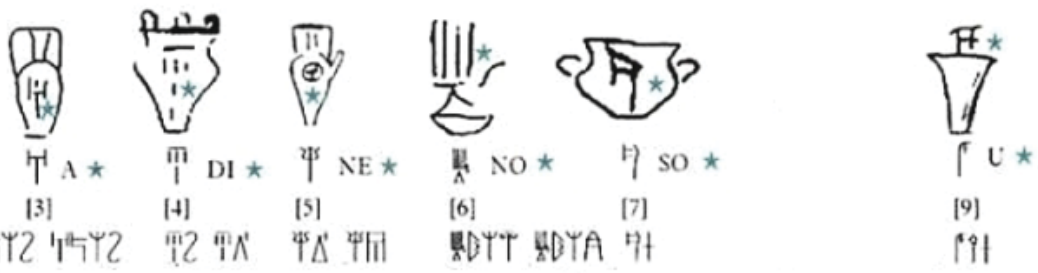

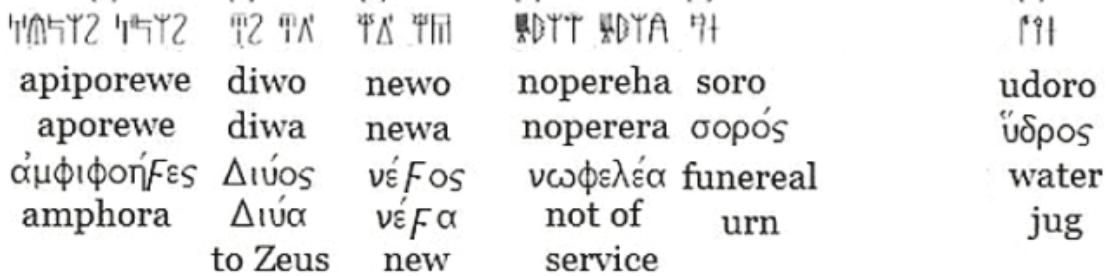

(C) by Richard Vallance Janke 2016

Table 3 - Supersyllabograms in the vessels sector of the Minoan/Mycenaean economy.

supersyllabograms in the vessels and pottery sector at great length. It was in that article that I fully addressed all of the possible variants of the supersyllabogram PO (pg. 153). Of the variants attributable to PO, Potiniya, the goddess Potnia, now seems after due consideration to be the best bet. In order for you to truly appreciate the great impact of super- syllabograms on the vessels and pottery sector of the Minoan/Mycenaean economy, I strongly urge you to read that article, as there is no point rehashing the analytical and synoptic progress I forged for these supersyllabograms in it.

We close out this section with an illustration of 4 tablets and fragments sporting supersyllabo- 

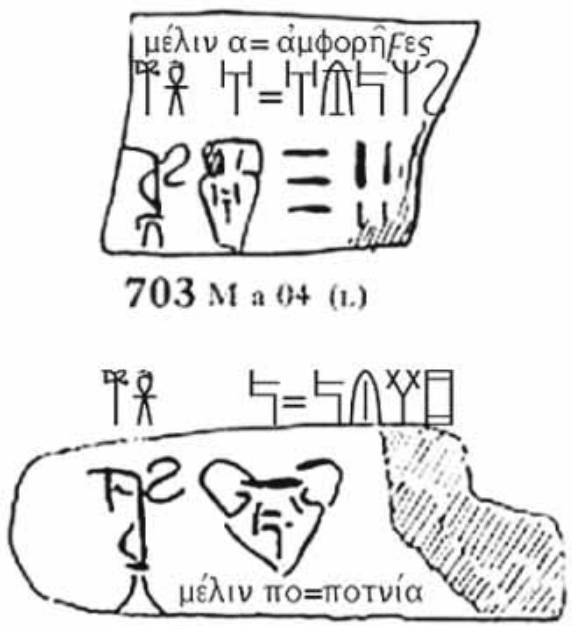

$8 \mathrm{~b}$, i $01(\mathrm{x})$

Translations:

$\mathrm{KN} 703 \mathrm{M}$ a 04: 34 amphorae of honey

$\mathrm{KN} 700 \mathrm{M} \mathrm{i} \mathrm{01:} 300+900$ new amphorae $300+900$ new amphorae ?dami? $1+$

$\mathrm{KN} 8 \mathrm{~J}$ i 01: an amphora of honey for the goddess Potnia

$\mathrm{KN} 776 \mathrm{~b} \mathrm{M}$ f o1: 1 jug of water

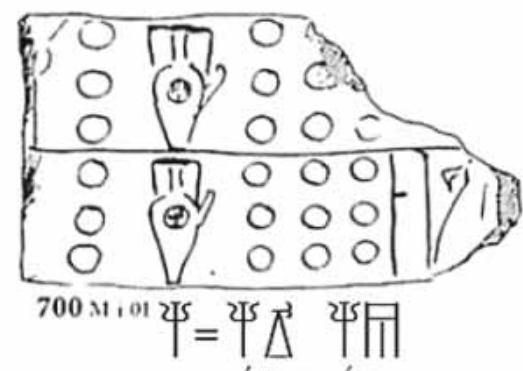

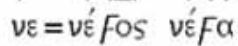

his $776 b \mathrm{M}: 0$

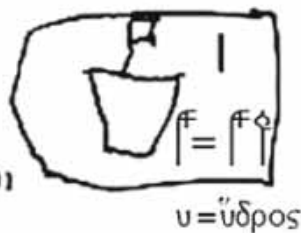

Supersyllabograms are shorthand.

(C) by Richard Vallance Janke 2016

Fig. 9 - Supersyllabograms for pottery in Mycenaean Linear B.

grams in the vessels and pottery sector (Fig. 9).

All of the SSYLS on these 4 tablets are self-explanatory. I do wish to call your attention to the supersyllabogram NE on fragment KN $700 \mathrm{M}$ i 01 (top right). This SSYL NE newo/newa = new, which appears in the vessels and textiles sectors, is one of only 5 which convey the same meaning across economic sectors. The others are KI kito = chiton, $\mathrm{KO}$ kowo $=$ fleece, $\mathrm{RI}$ rino $=$ linen and $\mathrm{WI}$ wirineo $=$ made of leather, all of which appear in both the military and textiles sectors.

Supersyllabograms in the textiles sector of the Minoan/Mycenaean economy:

Here we have the Table of Supersyllabograms in the textiles sector of the Minoan/Mycenaean economy (Table 4).

Table 4 lists the supersyllabograms in the textiles sector, all of which are attributive (at), as is to be expected. Assigning scalar weights to the supersyllabograms in this chart, we have: KI kito chiton $=4 \mid$ KO kowo $=$ fleece $=3 \mid$ KU kuruso $(y o)$ $=\chi \rho v \sigma o ́ / \varsigma \mathrm{xruso} / / / \mathrm{io}=(\mathrm{of})$ gold $=3 \mid \mathrm{NE}$ newo/ newa $=$ new $=4 \mid \mathrm{O}$ opa $=$ ollpa $=$ (syn., apudosis $=\alpha 0 \pi \dot{v} / \delta$ oor $\varsigma)=$ delivery $=2 \mid$ PA pawea $=\varphi \alpha ́ /$ $\rho F \varepsilon \alpha=$ textiles $=3 \mid \mathrm{PE}$ pekoto $=\pi \varepsilon \dot{\varepsilon} / \kappa o \tau \mathrm{ov}=\mathrm{a}$ kind of textile or a process in the refinement of textiles $=3 \mid \mathrm{PU}$ pukatariya $=$ fugate $/$ ria $=\mathrm{a}$ kind of textile or a process in the refinement of textiles $=3 \mid \mathrm{RA}$

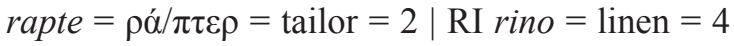
| TE tetukowoa $=\tau \varepsilon \tau v \chi v / / F_{\mathrm{o}} \alpha=\mathrm{a}$ kind of textile or a process in the refinement of textiles $=3 \mid \mathrm{WE}$ wehano $=F \varepsilon h \alpha v o ́ / \varsigma=$ a kind of textile or a process in the refinement of textiles $=3 \mid \mathrm{WI}$ wirineo $=$ $F \rho i ́ / v \varepsilon ı \varsigma=$ made of leather $=4 \mid \mathrm{ZO}$ zone $=\mathrm{zw} / \mathrm{nh}$ $=$ belt $=2$. The fact that there are so many supersyllabograms in the textiles sector bears witness to its great significance in the functioning of the Minoan/Mycenaean economy.

The following table serves to clarify the structure of incharged supersyllabograms in the textiles sector, with our attention trained on the unusual appearance of the supersyllabogram $\mathrm{RA}=$ rapte $=$ tailor (Table 5).

You can see for yourself that the supersyllabogram RA is peculiar. While it is incharged, in what sense is it incharged? The answer is in the pro- 


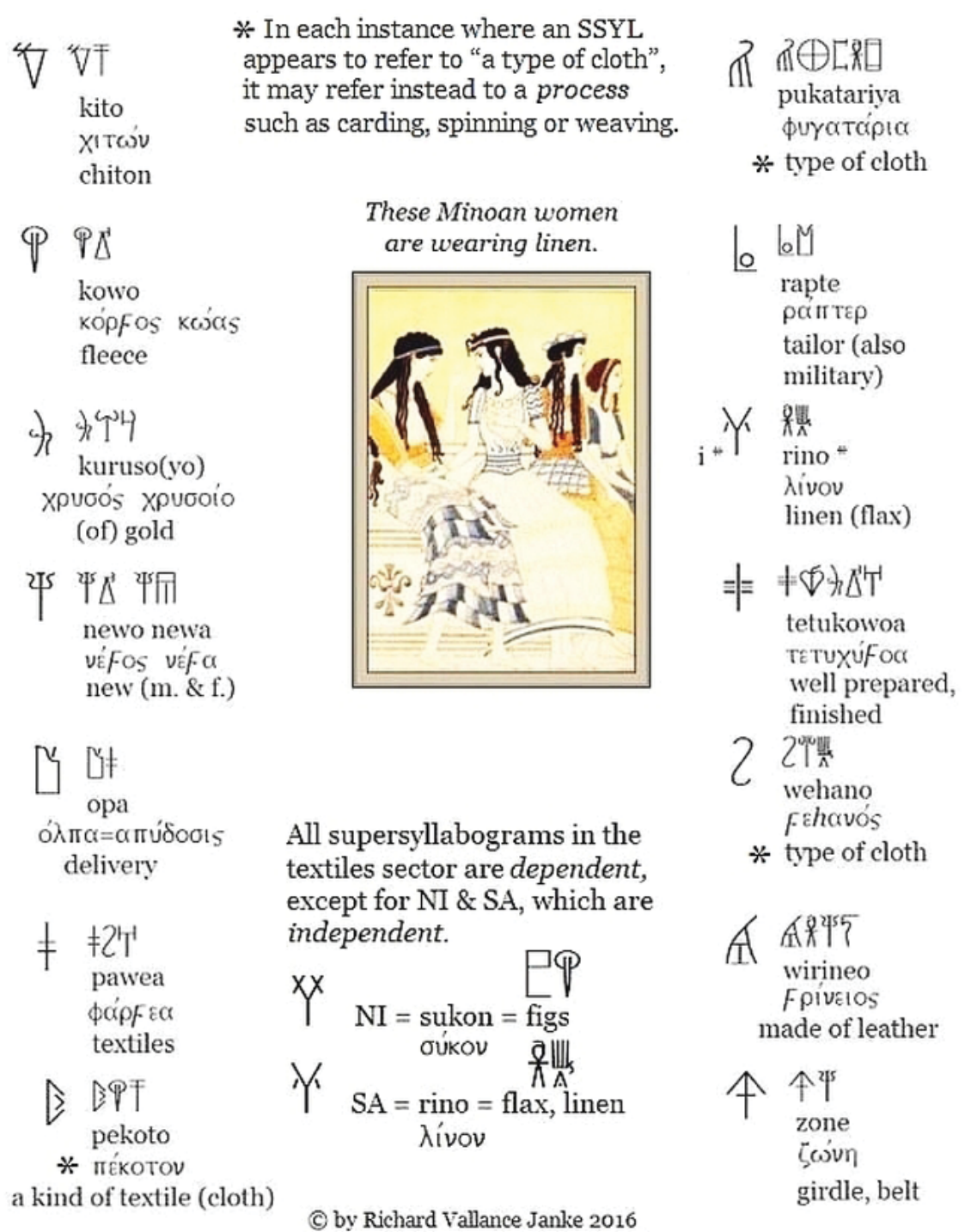

Table 4 - Supersyllabograms in the textiles sector of the Minoan/Mycenaean economy.

fession. A tailor works on an unfinished piece of cloth or textile which he fashions into a tunic, undergarment or any other article of clothing. Taking a closer look at this supersyllabogram, we note that it is positioned to the left and at the bottom of the ideogram in which it is incharged. We are confronted with another ideogram to the top and to the right which appears to be truncated. And it is. If we look closely at this ideogram, we can see that it looks very much like $1 / 2$ of the ideogram for rino $=$ linen (See Table 2 above, Military Supersyllabograms). If that is indeed the case, then it naturally follows that what we are dealing with here is unfinished cloth. The interpretation fits.
This is not to say that it is correct. This is why I have assigned a scalar value of 2 to the SSYL RA in textiles (Fig. 10).

Zeroing in on the supersyllabogram TE on this tablet, we find that Chris Tselentis, in his Linear B Lexicon, defines it as "well prepared" or "ready". But what does this imply? Once again the scribes must have assigned a more precise sense to the supersyllabogram TE. I believe that what they intended it to mean was "finished (cloth)" on the one hand, or "ready for sale on the open market" or simply "for sale" on the other.

Until now, the research community of philologists and linguists has, without exception, treated 


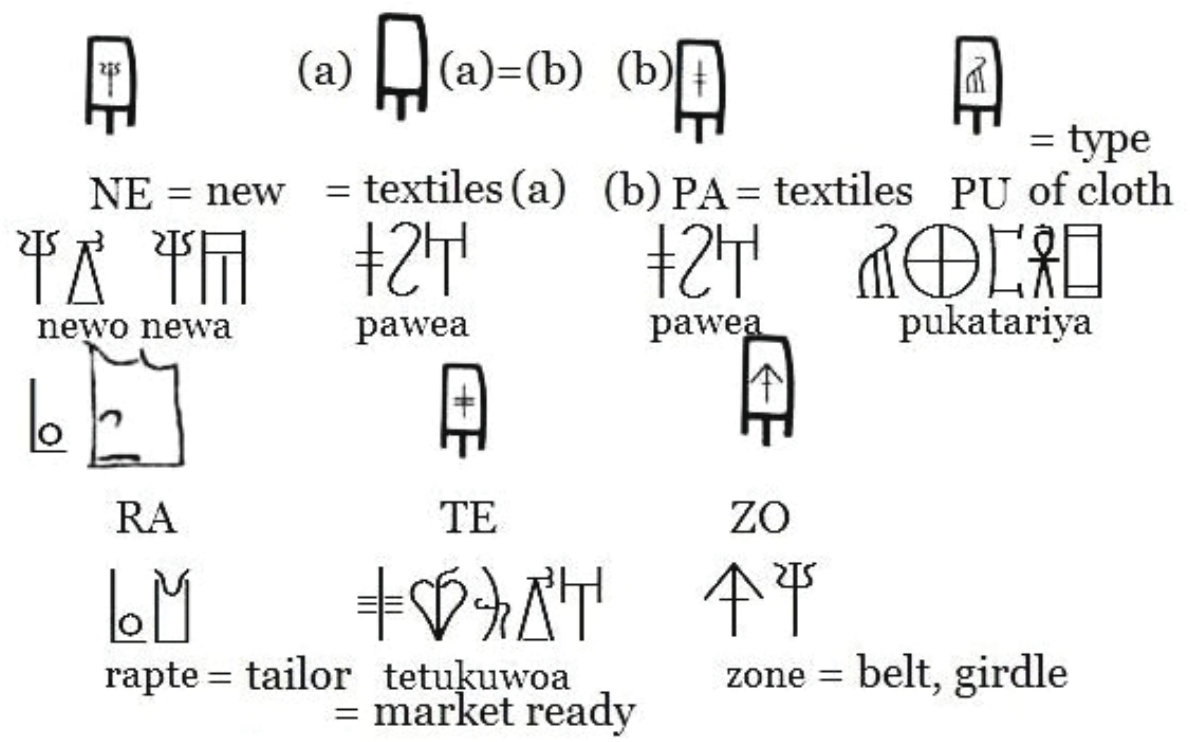

(C) by Richard Vallance Janke 2016

Table 5 - Supersyllabograms in textiles.

all of these supersyllabograms as being different types of cloth, given that they are all subsets of the generic ideogram for "textiles", namely, the blank ideogram in Table 5, which in its own turn is more often than not incharged with PA pawea $=$ textiles. The meaning of the incharged SSYL PA (textiles) appears to be confirmed, which is why I have assigned it a scalar weight of 3. Still, I am uncertain of the true values of the four SSYLS PE, PU, TE, TU and WE. Combinations of some or all four of these supersyllabograms may also or instead refer to a process in the production of textiles, such as dying (see Figure 11), spinning, weaving or carding. But we shall never know, because all four of these textile terms are archaic Mycenaean Greek, having disappeared from ancient Greek forever after the fall of Mycenae ca. 1200 BCE.

In summary, then, here are all of supersyllabograms in the textiles sector (Fig. 11).

Translations: 2 units of cloth of gold $=6+2$ units of linen cloth + ideogram for "cloth" +20 units of TE tetukowoa $=$ a kind of textile +1 unit of tunano $=$ Tuvávov $=$ a type of cloth $\mid$ WE wehano $=$ a kind of textile $\mid \mathrm{WI}$ wirineo $=$ made of leather $\mid \mathrm{ZO}$ zone $=$ a belt or girdle $\mid$ rita? (unknown word $)+$ pawea $=$ textiles $+($ left-truncated $)$ ?teweya (unknown word, left truncated) = a kind of cloth? + the ideogram for "cloth" | KI kito = chiton $\mid$ ekisiya (unknown word) = "'kı of cloth? + pekoto $=$ a type of cloth +2 units of TE tetukowoa $=$ a kind of textile +2 units of the ideogram for "cloth" (pawea).

Supersyllabograms in the agricultural sector of the Minoan/Mycenaean economy:

If supersyllabograms predominate in the military, vessels and pottery and textiles sectors of the Minoan/Mycenaean economy, they proliferate in the agricultural sector. Astonishing as it may seem, over $80 \%$ of all supersyllabograms appearing in all sectors of the Minoan/Mycenaean economy occur in the agricultural sector alone. Taking the approximate total of some 3,500 tablets and fragments unearthed at Knossos as our benchmark, we find that a subset of some 800 or $23 \%$ feature supersyllabograms. In turn, a slightly smaller subset of around $640(80 \%)$ tablets fall in the agricultural sector alone. What is even more astonishing is the fact that fully $90 \%$ or about 580 tablets of all the supersyllabograms in the agricultural sector are specifically related to sheep (rams and ewes).

Researchers have attempted to account for this huge disparity between all SSYLS in the military, 


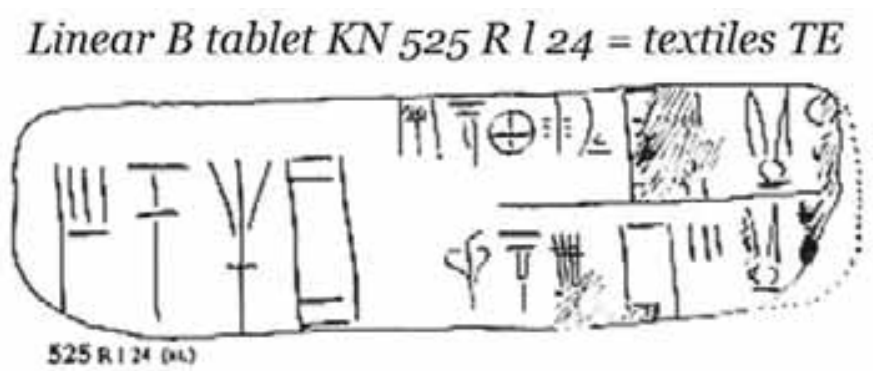

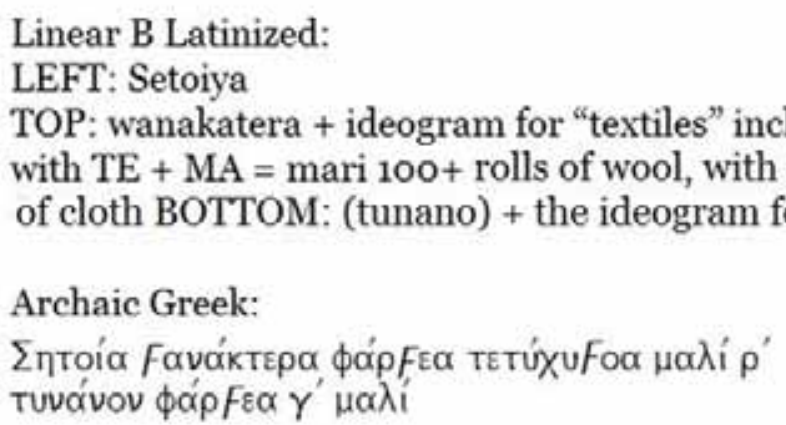

\section{Translation: \\ Seitoia (the Queen) in the Queen's Megaron *, with finished cloth, with a type of cloth (tunano) as 3 reams of textiles and ? rolls of wool.}

\section{* the Queen's Megaron * lit. the palace}

(C) by Richard Vallance Janke 2016

Fig. 10 - Supersyllabogram TE for textiles.

vessels or pottery and textiles sectors put together as a whole (amounting to no more than around 160 tablets) on the one hand, and the 640 or so supersyllabograms found on tablets in the agricultural sector alone on the other. In all likelihood, the Linear B scribes were far more focused on the agricultural sector than on any other because it would appear that the major revenues of the palace administrations at Knossos, Pylos and elsewhere accrued for the greatest part from the sheep husbandry and raising sub-sector of the agricultural sector, in spite of the fact that tens of thousands of vessels and pottery are inventoried on far fewer tablets in that sector. It does stand to reason that sheep would account for the major portion of palace revenues by some stretch, given that sheep husbandry and raising was very labour-intensive, and involved not only raising flocks from infancy (lambs), sheep shearing, the manufacture of wool and all other related activities, but primarily tending to flocks running to the 1,000 s and even the tens of thousands, up to as many as close to 100,000 at Knossos.

This is confirmed by the fact that in the same sector (agriculture), the raising of cows and bulls and the submission of bulls or oxen to teams at the yoke account for only 6 tablets in all (KN 896 D o 21 to KN $900 \mathrm{D}$ o 01). The discrepancy between the vast number of tablets with supersyllabograms dealing solely with sheep and those covering cows, bulls and oxen is so wildly lopsided as to defy "common sense". But there you have it.

Here we have the Table of Supersyllabograms for those 580 or so tablets dealing with sheep in 


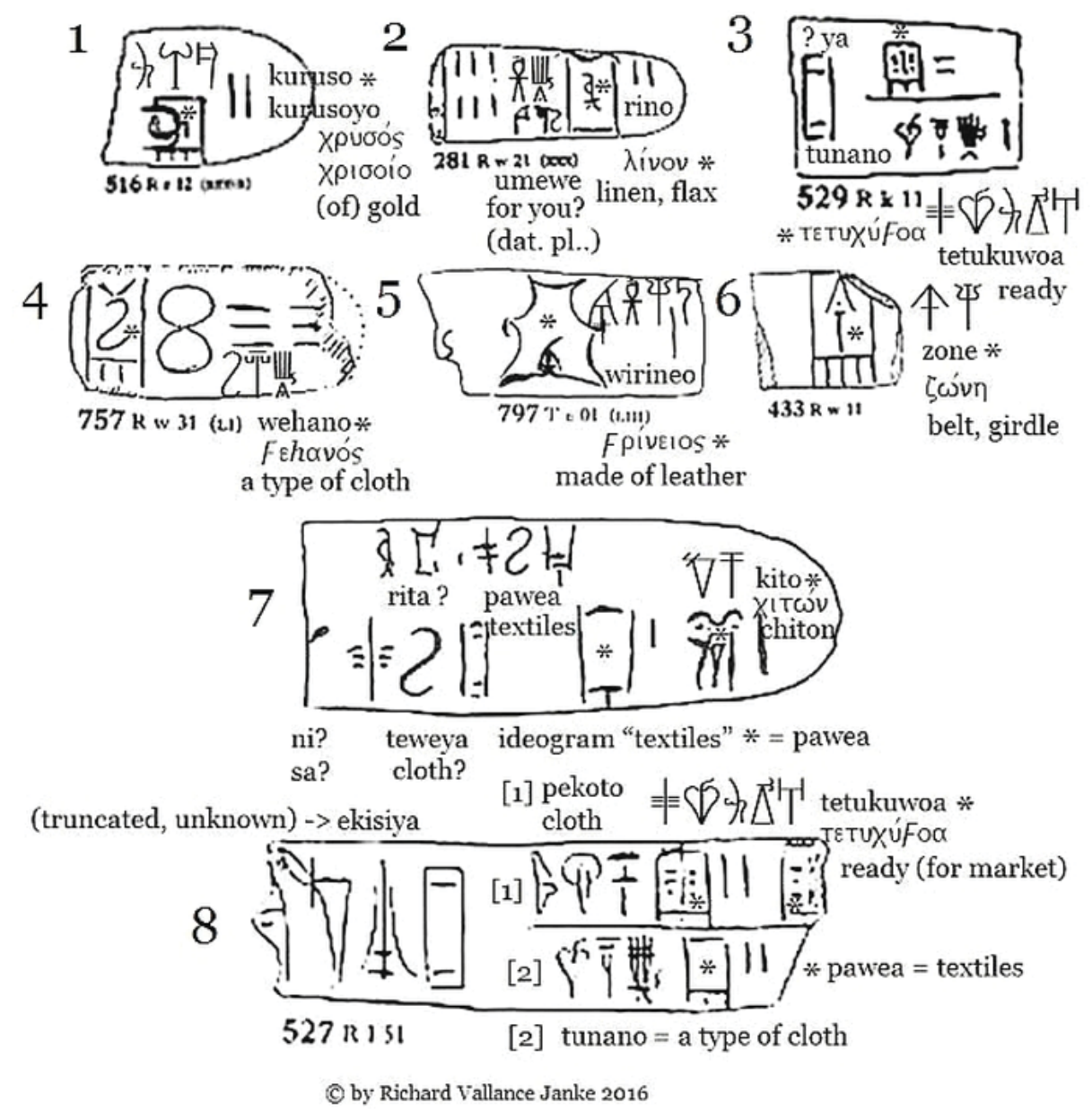

Fig. 11 - Supersyllabograms for textiles in Mycenaean Linear B.

the agricultural sector of the Minoan/Mycenaean economy (Table 6).

Table 6 lists the supersyllabograms in the agricultural sector, all of which are associative (at), contrary to all the other sectors, in which there are either admixtures of attributive and associative supersyllabograms (military) or associative supersyllabograms alone (vessels and textiles). Assigning scalar weights to the supersyllabograms in this chart, we have: KI kitimena $=$ a plot of land $=$ $4 \mid \mathrm{O}$ onato $=$ a lease field $=4 \mid$ PA pauro maûpos $=$ small or little, i.e. lambs $=2 / 3 \mid$ PE periqoro $\pi \varepsilon \rho i ́ \beta о \lambda о s=$ sheep pen $=3 \mid$ SA sapaketeriya $\sigma \varphi \alpha \kappa \tau \eta \rho / i ́ \alpha 1=$ for ritual slaughter $=2 \mid$ SE sekazo

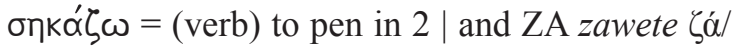
$F \varepsilon \tau \varepsilon \varsigma=$ this year $=3$. The values for $\mathrm{KI}$ and $\mathrm{O}$ are absolutely certain, as the extant Linear B lexi- con allows for no other interpretations. Those for $\mathrm{PE}$ and ZA are highly probable, since these two words figure prominently in the Linear B lexicon. SA and SE cannot be assigned weights higher than 2, because neither term is attested anywhere in the Linear B lexicon. I was obliged to ransack the Pocket Oxford Classical Greek Dictionary for both of these terms. As I have emphatically stressed before, there is no assurance whatsoever that Classical Greek words represented as sapaketeriya and sekazo in Linear B actually existed in Mycenaean Greek. However, they do make eminent sense in context.

PA or pauro = small, little, i.e. "lamb" is a special case. Once again, there exist no attested instances of this supersyllabogram spelled out in full on any extant Linear B tablets, in spite of 


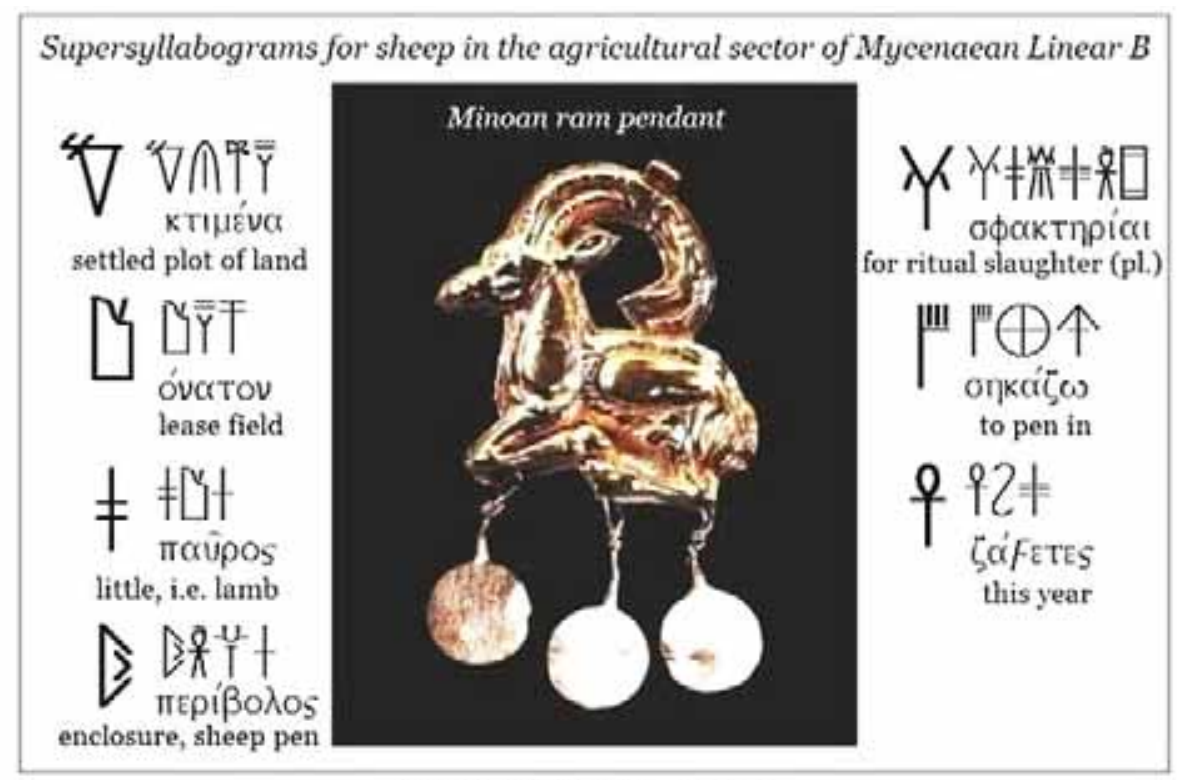

Bo by Richard Vallance Janke 2016

Examples of supersyllabograms for sheep
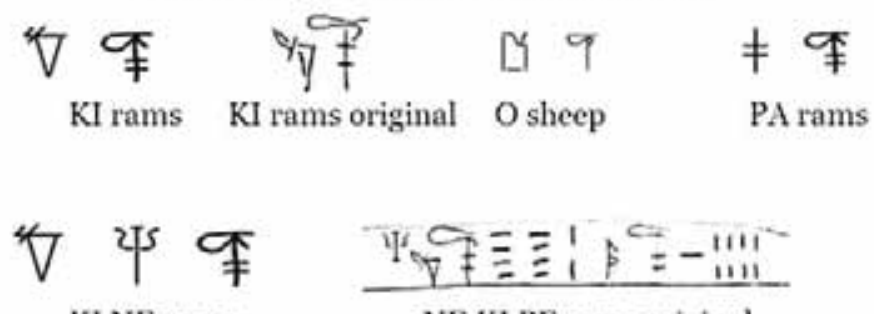

KI NE rams

NE KI PE rams original

(S) by Richard Vallance Janke 2016

$$
\text { Ff } 1=\begin{aligned}
& + \text { the supersyllabogram } \mathrm{ZE} \text { for bulls \& oxen } \\
& \mathrm{T}
\end{aligned}
$$

Table 6 - Supersyllabograms for sheep in the agricultural sector of Mycenaean Linear B.

the fact that this SSYL PA accounts for no fewer than 38 tablets. So it is obvious that the Linear B scribes held the SSYL PA in great stock. You will recall from my discussion of this supersyllabogram in Criterion 1 above that I assigned the meaning, "lambs" to it for various cogent reasons. The clincher is that on every last one of the tablets on which the SSYL PA figures, the number of "little" sheep associated with it is always much smaller than the total number of sheep on the same tablet. What is even more significant, the number of tablets on which the ideogram for "ewe(s)" figures $=27 / 37$ or $73 \%$ always treat of lambs. This factor alone signifies that the commonplace pres- ence of the ideogram for "ewes" could account for PA "lamb(s)" on the same tablets. Moreover, the number of lambs (if that is what PA means) is always less than the number of ewes. For the reasons outlined in Criterion 1 above and the last one cited here, I have deemed it expedient to raise the scalar value of PA from 1 to $2 / 3$.

I conclude with 6 Linear B tablets in the sheep sub-sector of the agricultural sector, all of which serve to illustrate not only the accuracy of supersyllabograms in this sector but their intrinsic economy, in the sense that they replace discursive text which would have otherwise cluttered up these tablets, had they been spelled out in full. 


\section{Figure 12}

Supersyllabograms in the sheep husbandry sector of the Mycenaean economy

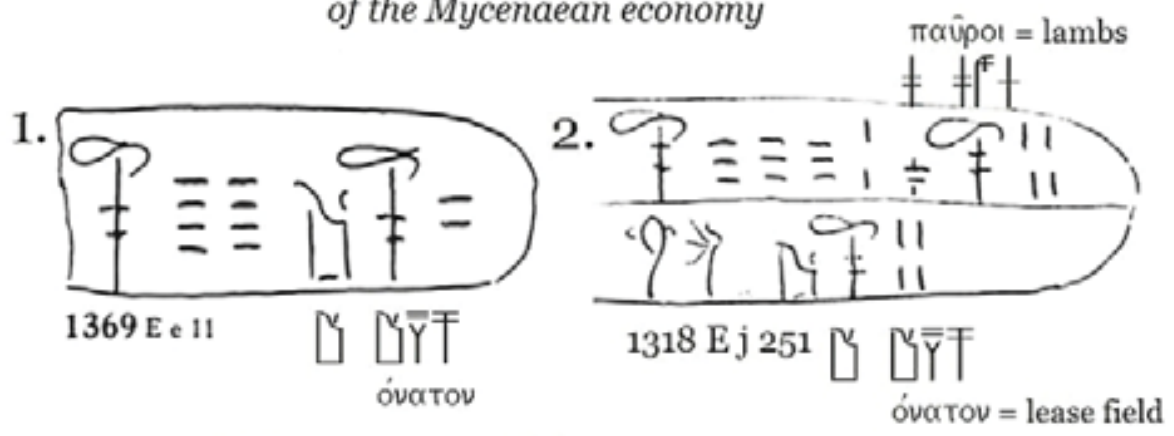

1. 80 rams \& 20 rams on a lease field
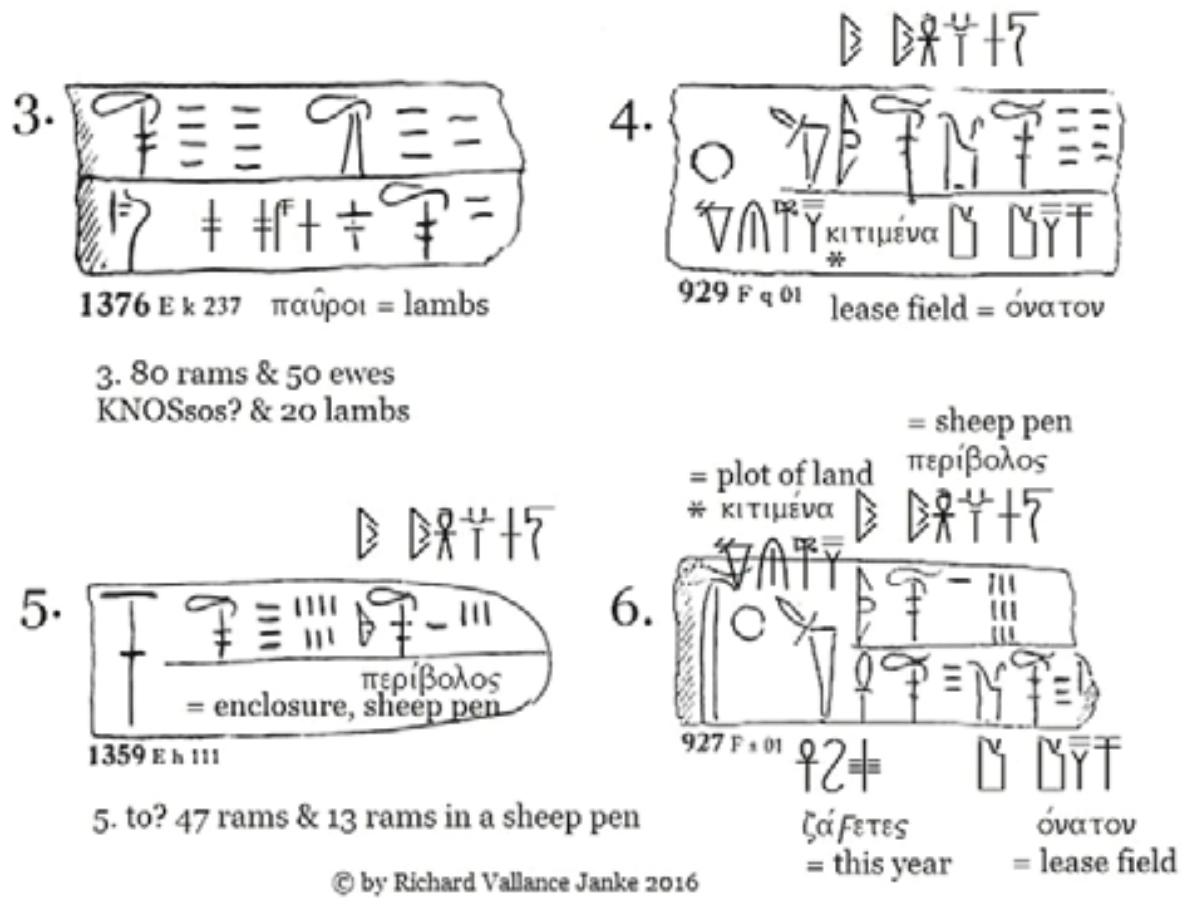

Fig. 12 - Supersyllabograms in the sheep husbandry sector of the Mycenaean economy.

We shall return to this prime characteristic of all supersyllabograms, regardless of sector in the conclusions to this study, with an extension of the sense of economy to a wider interpretation which is likely to astonish you.

Here are the 6 tablets to which I have just referred (Fig. 12).

While I was able to translate some of these tablets in this figure, I could not do so for all of them for lack of space in it. I shall do so now.

Tablet 2 translates as follows:

62 rams 4 male lambs qamo? (unknown) +4 rams on a lease field. Qamo appears to be undecipherable but I suspect it is the name of the owner or shepherd, "Bamos".

Tablet 4, which is illustrative of the greatest possible economy served by supersyllabograms on Linear B tablets, because there is no text on it all, reads as follows:

a ram in a sheep pen on a plot of land (I have spelled out kitimena, "a plot of land", which is symbolized by the SSYL KI on this tablet) and 80 rams on a lease field. (I have spelled out onato, "a lease field", which is symbolized by the SSYL O 
on this tablet.) It is extremely significant that this tablet deploys only 3 supersyllabograms to replace what would otherwise have been wasteful text.

Tablet 5 translates:

(Kosou)to (a name left truncated)+ 47 rams + 13 rams in a sheep pen. Once again, apart from the putative name of the shepherd, Ksouthos, there is no text at all on this tablet. No surprise here by now.

Tablet 6 , heavily abbreviated, is the most economical of them all. There appear no fewer than 4 SSYLS on it, if you can believe that. I would, if I were you, because there is even one tablet in the sheep sub-sector which sports 5 supersyllabograms with no text at all. So once again, this greatly condensed tablet, deploying only SSYLS, reads:

100 ewes, 19 rams in a sheep pen, 30 rams from this year's flock on a plot of land and 31+ rams on a lease field. If spelled out in full, these words would have run as follows: kitimena periqoro zawete onato, consuming 10 syllabograms consisting of 19 characters, instead of the 4 supersyllabograms consisting of 8 characters on the actual tablet. The total of syllabograms alone on the hypothetical tablet add up to just shy of 3 times the number of syllabograms on the real tablet, given that supersyllabograms are a subset of syllabograms. The number of characters on the conjectural tablet $=19$ versus 8 on the actual tablet (a little less than 2 and a half times).

The whole point of this exercise is to demonstrate beyond a shadow of a doubt that supersyllabograms are so economical of space on what are after all extremely small tablets that it is no wonder that the scribes resorted to this stratagem over and over. The phenomenon of the supersyllabogram is, in short, an amazingly effective invention on the part of those ingenious Linear B scribes of the distant past (over 32 centuries ago). More on the marvel of this rarest of linguistic practices in our conclusions.

Olive oil production in the agricultural sector:

There is one other sub-sector of the agricultural sector which demands our scrupulous attention. This is the olive oil production sub-sector. While, as with the other sectors of the Minoan/Mycenaean economy (military, vessels and textiles), there are only a few tablets featuring olive oil processing and consumption, this sub-sector is of particular significance strictly from the point of view of semantics. Here we have Table 7, Supersyllabograms for olive oil in the agricultural sector.

These supersyllabograms are of the utmost import in the effective decipherment of Mycenaean Linear B. The rest of the attributive supersyllabograms except $\mathrm{TI}=$ tithasos $=$ a cultivated olive tree and WE weyewe = "this yea(r's crop or harvest)" raise serious doubts in my mind with respect to the research into their semantics conducted by the renowned philologist José L. Melena, in his seminal study, "Olive Oil and Other Sorts of Oil in the Mycenaean Tablets" (1974) [ ${ }^{6}$,bis], as well as that of other prominent researchers in the field, who almost invariably fall prey to the same cast of semantic errors as does Melena. Referencing Melena's study on supersyllabograms in the olive oil sub-sector of the agricultural sector, we discover to our great disappointment that he has attributed capricious "meanings" to some of the supersyllabograms relevant to olive oil production. The question is why?

Let us carefully examine in turn most of his translations of the supersyllabograms A, KU, PA, SI, TI \& WE. Beginning with A, Melena attributes the singularly peculiar sense of "wild olives" as attested by the conclusion he reaches on page 101: "As a conclusion we infer from the palaeoethnobotanical evidence that there were at least two kinds of olives in Crete during Minoan and Mycenaean times, and that there is then certain material support for the interpretation of the ligatures $+\mathrm{A}$ and + ? as standing for two kinds of OLIV. Moreover, it is likely that one of these kinds of olives was wild, and the other an early cultivated plant, a fact that would strengthen the proposal advanced by Dr. Chadwick of A standing for agrios for 'wild' and of 77 doing for tithanos 'domesticated'. At this point, a justification of the Mycenaean preference for 'wild' A olives, as can 


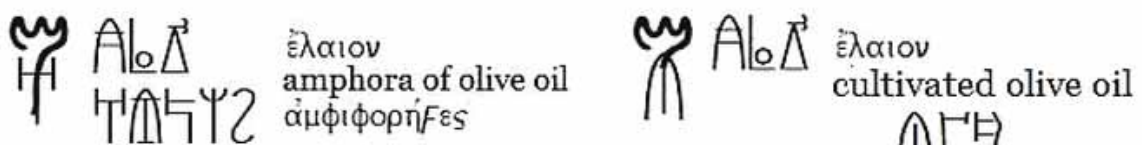 \\ These 2 supersyllabograms are attributive.

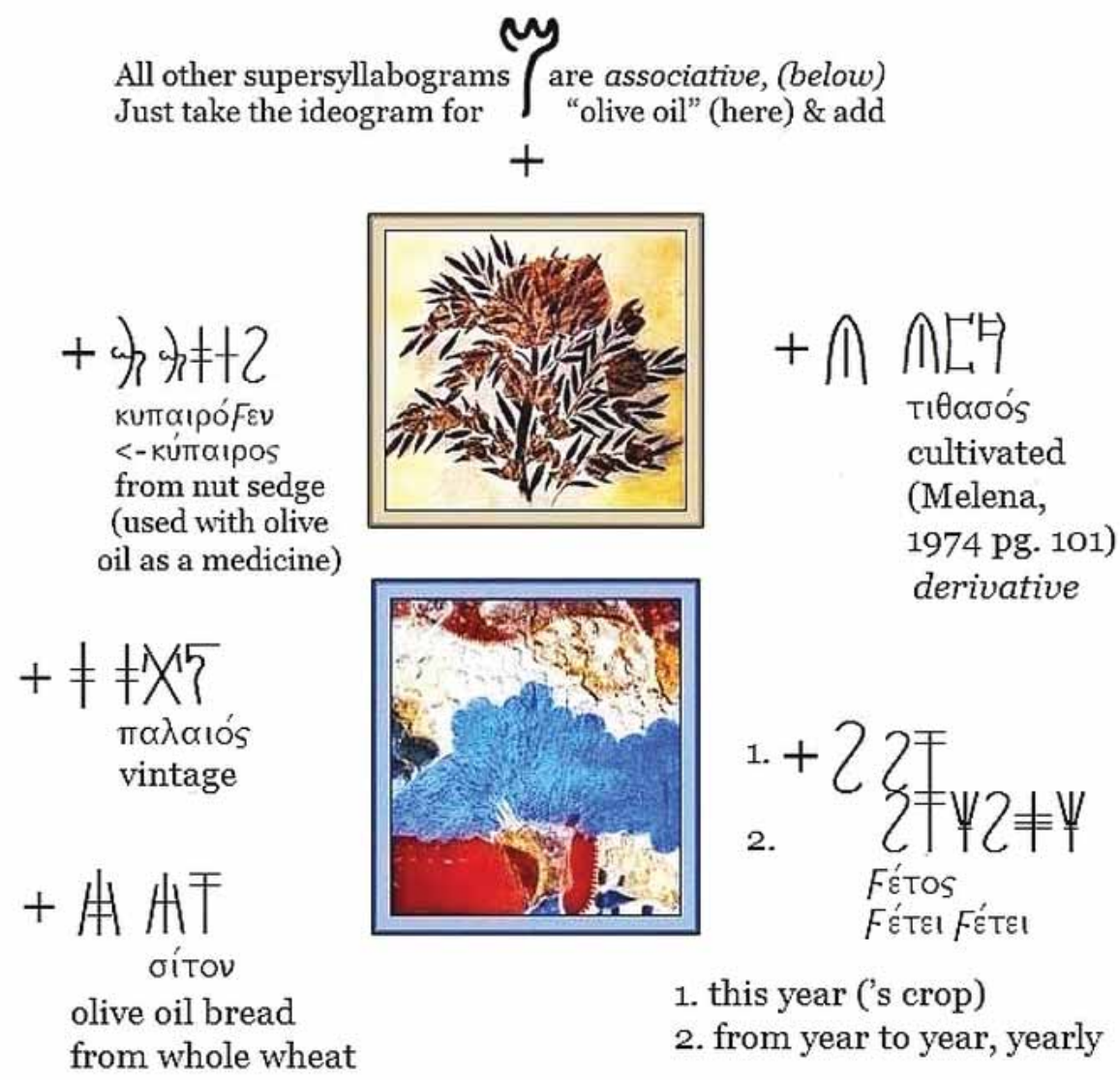

(C) by Richard Vallance Janke 2016

Table 7 - Supersyllabograms for olive oil in the agricultural sector.

be easily seen in the tablets, is needed."

Easily seen? By what criteria? The glaring problem with the first of these interpretations, agrios $=$ 'wild', is that it simply does not make any sense in the context of olive oil production in Minoan-Mycenaean Greece. Returning to our discriminative question, why, the answer is not long coming. Instead of interpreting the supersyllabogram for what it incontestably must mean, i.e. olive oil in amphorae (Linear B, aporewe), he goes off on an academic tangent, struggling for dear life to dredge up a "meaning" which does not in the least bit suit the context of olive oil production. It is patently obvious that no one in their right mind would resort to trying to cultivate wild anything let alone wild olives in any productive agricultural practice. Wild plants are singularly resistant to cultivation; so I have to wonder why Melena opted for such a bizarre translation. All the more so in light of the incontestable fact that the Minoans at Knossos, Pylos and elsewhere stored their olive oil in huge amphorae, otherwise known as Greek pithoi in Classical times. (See Linear B tablet TA 641-1952) [2, bis] for a conclusive confirmation of my own decipherment, which is indeed aporewe in Linear B = amphora.

Why then did Melena settle on this strange decipherment? The reason is self-apparent: he is 
an academic. We academics in ancient linguistics are plagued by a regrettable penchant for seeking out decipherments or translations which are, in a word, academic. But the inherent fault-line in such an approach is that it is invalid by its very nature.

Criterion 2 incontestably bears repetition. We must rigorously apply the unequivocal principle that the Linear B scribes always resorted to supersyllabograms equivalent to determinative terminology which was invariably descriptive of a major, never a minor, aspect of the métiers, activities, commodities and end-products intrinsically proper to any of the four major sectors of the Minoan/Mycenaean economy, be it the military, vessels and pottery, textiles or agricultural sector. This is far and away the paramount consideration to be taken into account in the allocation of accurate terminology of Linear B vocabulary commensurate with the polysemiotic values of each respective supersyllabogram.

The problem with Melena's implausible decipherment of A = "wild olives" is that it does not in the least relate to the principle - and I emphatically repeat - that the Linear B scribes always deployed terminology equivalent to supersyllabograms which was invariably descriptive of a $m a-$ jor, never a minor economic factor. Put another way, what we academics in historical linguistics frequently and so blithely neglect is the incontrovertible fact that the Linear B scribes were as far from being "academics" as the modern academic world is as far removed from their real word. There simply was no academia in the modern sense of the word in Minoan/Mycenaean society, let alone in any society in antiquity, even as late as Classical Greece and Rome. The language of the Mycenaean scribes was strictly that of accounting and inventory, and what is even more significant, it was invariably formulaic. Why so many academics fail to realize this basic fact is a mystery to me. Any translation of any supersyllabogram in Mycenaean Linear B must be an actual indicator of a major economic term in any of the four major sectors of the Minoan/Mycenaean economy - "major" repeated again for emphasis. Mycenaean tabular terminology has nothing to do with academic translations. Period.

The Linear B scribes were keepers of inventories, in other words, accountants, and nothing more. But accountants of what? Their inventories invariably turned on the four major sectors of the Minoan/Mycenaean economy, the military, the vessels and pottery, the textiles and above all else, the agricultural. The language they used to compile their inventories was completely standardized and strictly formulaic in the extreme. In spite of the great distances separating the major cities and economic centres of the Mycenaean economy, Knossos, Pylos, Mycenae, Thebes and so on, the Mycenaean Greek of the tablets, of which there are some 5,000 all told from all provenances, does not vary one jot, with the exception of some minor quirks of "style" of some of the scribes. In other words, the Mycenaean of the inventorial tablets is a totally artificial construct, entirely based on the necessity of compiling accurate, fully standardized inventories of the four major sectors of their economy. And this is precisely why so many historical philologists are entirely on the wrong track, Melena far from being the only one. All of this implies - just short of explicitly - that every last supersyllabogram must, by its very nature, be a major term in the Mycenaean economy. Otherwise, it is invalid by nature.

To illustrate my point even further, let us continue with our close examination of Melena's other decipherments, which equally stretch the bounds of credibility. While his interpretation of the SSYL TI = tithasos = "cultivated olives", does make eminent sense (scalar weight $=3$ ), in spite of being derivative and unattested, I will leave it at that, given that here he has not allowed his academic prejudice to adversely colour his translation. But his decipherment of the supersyllabograms SI and WE begs credibility.

WE he unaccountably deciphers as, and I quote:... "The latter group has abbreviated accounting items by means of a pair of ligatured 
ideograms (OLE + A and OLE + WE, standing acrophonically for $a$-ro-pa $=\alpha^{\prime} \lambda \varepsilon i ́ \phi \alpha=$ Greek oil 81 and we-ya-repe $=$ Фєı ly),..." Here again, reverting to the SSYL A, in flat out contradiction to his previous interpretation of Greek agrios "wild", he confers yet another sense on it, aropa, which he erroneously translates as "oil", rather than taking to its true meaning = "cream" or "ointment" as meaning agrios (Tselentis), and this after he had previously deciphered it as meaning agrios = ă $\gamma p$ p ing at straws. But you cannot have it both ways.

SI he unaccountably derives from Linear B siaro $=$ Greek sialos $=$ "pig", stretching that term to the point of absurdity by claiming it refers to "an ointment made from pig fat." But siaro does not mean "pig fat". It means "pig" and nothing else. So this one is truly beyond credibility. Who on earth would even remotely want to use an ointment of pig fat mixed with olive oil? But he has realized that SI is indicative of "abbreviated accounting". He at least nails that head on. In other words his translations, however inaccurate some of them are, are squarely set in the context of supersyllabograms as we now understand them.

Now SI almost certainly refers to Linear B sito = wheat.. It only takes a moment's consideration to realize that olive oil rolled into whole wheat and baked in a kiln yields olive oil bread, a staple of the ancient and modern Greek diet. And there you have it. In case anyone is wondering why SI is not attributive, I put it to you that wheat is not necessarily attributable to olive oil, but only associated as a crop. Now it just so happens that the Linear B scribes never resorted to adjectives to describe associative supersyllabograms, but always characterized them as nominative (i.e. nouns), given that no single associative supersyllabogram is necessarily related to another, with a strict emphasis on necessarily. It just so happens that the scribe has conjoined the SSYL SI with the ideogram for olive oil, simply because he deliberately intends to combine the two into a cohesive whole which, in this particular configuration, re- fers to whole wheat olive oil bread. At least that is my interpretation. And let us not fail to recall that all supersyllabograms must refer to major activities, commodities, production and produce. From this perspective, the production of olive oil bread makes eminent sense. So I believe we are in a pretty solid position to assign a scalar value of 3 to the combination SI sitos = wheat with the ideogram for olive oil.

\section{CONCLUSIONS}

Is this the last major frontier in the full decipherment of Mycenaean Linear B?

Supersyllabograms play such a critical rôle in the complete decipherment of Mycenaean Linear B that they cannot safely be ignored. They function in virtually the same way as modern signage, which makes use of graphic images consisting of a single letter signifying an action (verbal) function or locality (nominal). For instance, a white $\mathrm{H}$ in a blue square signifies "hospital" (locative), a white $\mathrm{P}$ in a blue square "parking", a black P crossed diagonally by a red stripe in a white circle "no parking" (nominative), red, yellow and green lights on a black background signifying "go", "prepare to stop" and "stop", and "speed limit" consisting of the limit in white on a blue square, "Do not exceed $50 \mathrm{kmh}$." (the last 2 being verbal).

Supersyllabograms in Mycenaean Linear B go even further. As we have seen from the supersyllabograms in each of the four major sectors of the Mycenaean economy, agricultural, military, vessels and pottery and textiles, their functionality considerably outstrips that of modern signage, insofar as they can and do signify not only simple concepts as seen in modern signage, but are polysemiotic markers for (often highly) variable major concepts, often crossing from one of the major sectors to another. For instance, we have KI for kitimena, which means "a plot of land" in the agricultural sector, but KI for kito = "a chiton" in the textiles sector; in the military sector QE for 


\begin{tabular}{|c|c|c|c|}
\hline & [Supersyllabograms are in CAPS] & & bomopbones \\
\hline & 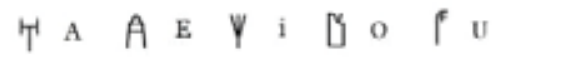 & & ha $\uparrow$ \\
\hline & $\vdash$ DA $\chi$ de T DI $i$ do $\mathbb{a}$ du & 36 & AI \\
\hline & Q ja or ya $X$ je or ye — Fjo or yohth ju or yu * & & $\begin{array}{ll}\text { ai2 } & \text { क } \\
\text { ai3 } & \text { के }\end{array}$ \\
\hline 10 & $\bigoplus \mathrm{KA} \quad$ w ke $\nabla \mathrm{KI}$ P Koid & & kwe B \\
\hline & $\forall$ ma $\uparrow$ me $V$ mi $\uparrow$ мо $\uparrow$ мU & & nwa ${ }_{\text {na }}^{X}$ \\
\hline & $\bar{Y}$ NA $\quad \psi N E \quad Y X$ NI id & & pte $\bigcup^{\prime}$ \\
\hline 20 & 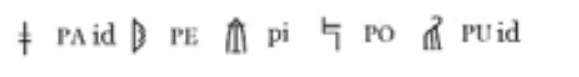 & & riya \\
\hline & 9 qa $\ominus$ QE $\rceil$ qi $\dagger$ qo - & & rai 单 \\
\hline & b RA $\Psi$ re $f$ RI $†$ Ro $\Psi$ ru & & siya \\
\hline & 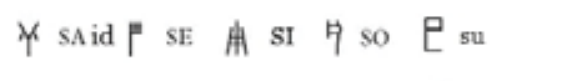 & & tiya 周 \\
\hline 30 & ᄃ ta $\neq$ TE $\bigcap$ TI $\subsetneq$ to $\oplus$ tu & & $\operatorname{swg} *$ \\
\hline & 用 wa 2 we $A$ wI $\Delta$ wo & & swilly * \\
\hline 35 & 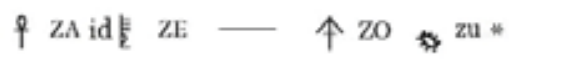 & & \\
\hline
\end{tabular}

Supersyllabogams tagged "id" are both independent and dependent.

(c) by Richard Vallance Janike 2016

Table 8 - Table of supersyllabograms in Mycenaean Linear B.

qeqinomeno for "made by twisting or winding", but QE qero = "a shield", and ZE zeugesi for "a pair of, a set of wheels on axle" and "a team of horses" (all of those under ZE being notable variants on one another); and finally in the textiles sector PA pawea for "textiles", referring to the textiles industry in general, whereas in the agricultural sector PA pauro = "small", apparently refers to lambs. The meanings of the same supersyllabograms across sectors are clearly distinct, hence polysemiotic. So while modern signage generally replaces simple concepts, supersyllabograms in Mycenaean Linear B very often signify much more complex economic activities and processes, as well as distinct commodities. While it is true that supersyllabograms are limited solely to the sphere of inventories in the four major economic sectors of the Minoan/Mycenaean economy, nevertheless within that ambit their polysemiotic symbolic functionality significantly exceeds that of modern signage.

But there is more. While graphic symbols in modern signage never represent more than one nominal concept or verbal activity, and are never used in combination with another such symbol, supersyllabograms are frequently concatenated with more than one ideogram (up to as many as five), especially in the agricultural sector. In such cases, both the multiple supersyllabograms and the ideograms with which they are coupled replace complex textual strings of major economic terms in Mycenaean Greek. For instance, the accumulative combinatory effect of the four concatenated supersyllabograms KI, PE, ZA and O on Linear B tablet KN $927 \mathrm{~F} \mathrm{~s} 01$ goes much further in their polysemiotic functionality than any modern example of signage conceivably ever could. On this tablet alone, on which there appears no text whatsoever, the cumulative translation of these 4 concatenated supersyllabograms amounts to nothing short of this entire sentence, "100 ewes, 19 rams in a sheep pen, 30 rams from this year's flock on a plot of land and $31+$ rams on a lease field." Astonishing! With all of this in mind, we at 
last turn to the table of all 36 supersyllabograms in Mycenaean Linear B (Table 8).

It is imperative to stress that these 36 supersyllabograms account for $\mathbf{5 9 \%}$ of the 61 syllabograms +1 homophone $(\mathrm{AI})=62$ total in Mycenaean Linear $B$. That is a huge investment on the part of the Linear B scribes in the now complete (2016), versus previously partial decipherment of Linear B. Note that of the 36 supersyllabograms, only 7 are both independent and dependent supersyllabograms. All of the others are dependent only, i.e. fused with a correlative ideogram. Dependent supersyllabograms must always accompany an ideogram, either preceding or following it, if they are associative (at), or incharged inside it, if attributive (as). The independent supersyllabograms, on the other hand, function alone, not attached to any ideogram. These include the 5 city names on Heidelberg tablet Fl 1994 (Figure 4) and the two SSYLS NI and SA in the textiles sector in Table 4, which respectively symbolize "figs" and "flax" or "linen" respectively, for a total of 7 independent supersyllabograms. So if any Linear B philologist or researcher was not previously convinced that supersyllabograms proliferate in Mycenaean Linear B, I fail to see how he or she is not finally prevailed upon to be won over.

Moving on, we recall yet again the two major Criteria for the establishment of the validity of each and every supersyllabogram, 1. supersyllabograms must be assigned a scalar weight in accordance to the level of validity they attain and 2. (which is far more important) each and every supersyllabogram must be reflective of a major term in any of the four primary sectors of the Mycenaean economy. In light of the brilliant Prof. L. R. Palmer's insistence that the fewest number of criteria are required to account for any and all phenomena relative to the decipherment of Linear $\mathrm{B}$, and I cite his eminently scientific principle, the principle of economy in full. ${ }^{12}$ "The number of hypotheses set up to explain a given set of facts is an objective measure of the 'arbitrary', and explanations can be graded on a numerical scale. A completely 'arbitrary' explanation is one which requires $\mathrm{x}$ hypotheses for $\mathrm{x}$ facts. It follows that the most 'economical' explanation is the least 'arbitrary'.” (Palmer, L.R., 1963, pg. 34) [italics mine].

Take special note of his unequivocal reference to the principle of economy, the very same which I have implied over and over with reference to supersyllabograms. I have posited only $\mathbf{2}$ criteria to account for the validity of all 36 supersyllabograms in Mycenaean Linear B. This is in full accordance with Palmer's principle of economy. If I had had to resort to 3 or more criteria, the validity of my own criteria would have been more seriously undermined with the addition of each new criterion. But by adhering to Prof. Palmer's principle of economy, I have entirely skirted this unscientific pitfall, with the sole exception of scalar weights of 1 or 2 as a subset of Criterion 1 which I have been unable to escape the consequences of. Still, it would have been disingenuous of me to have classified supersyllabograms at levels 1 and 2 otherwise in accordance with that criterion.

Furthermore, we must always keep uppermost in mind that when we change the context of the economic sector, for instance from the agricultural to the military or the vessels sector, we automatically change the meaning of the supersyllabogram, with very few exceptions. The supersyllabogram NE (Linear B Latinized), invariably meaning newo (masc.) newa (fem.)(Linear B Latinized) = "new" which appears in the vessels and textiles sectors, is one of only 5 which convey the same meaning across economic sectors. The others are KI kito = chiton, $\mathrm{KO}$ kowo $=$ fleece, $\mathrm{RI}$ rino $=$ linen and $\mathrm{WI}$ wirineo $=$ made of leather, all of which appear in the military and textiles sectors.

Now we arrive at the most significant conclusion of all. Whereas all supersyllabograms, which are intrinsically highly formulaic and fossilized, are representative of major (never minor) activities, processes and commodities of the Minoan/ Mycenaean economy, they are nevertheless highly flexible and malleable, in light of the fact that when the scribes cross from one economic sector to the 
next, practically all supersyllabograms, with very few exceptions (see immediately above) change their meaning, and usually radically. This striking feature of Mycenaean Linear B reveals yet another key characteristic of Linear B tablets which so frequently deploy supersyllabograms to replace Mycenaean words or phrases. Supersyllabograms in every single sector of the Minoan/Mycenaean economy effectively operate as shorthand. This startling discovery sets back the time frame for the first known use of shorthand some 3,300 years from the late nineteenth and early twentieth centuries. Once again, Mycenaean Linear B attains a high degree of versatility and sophistication virtually unknown to other contemporaneous scripts, hieroglyphic or syllabogrammatic.

Finally, we must never lose sight of the fact that any decipherment of Linear B in its totality which does not fully account for supersyllabograms is bound to be seriously compromised. We risk trammelling the complete decipherment of Linear B if we fail to take supersyllabograms fully into account. In light of the fact that some 800 (23\%) of 3,500 tablets and fragments from Knossos contain at least one supersyllabogram, any decipherment falling short of accounting for the critical rôle supersyllabograms is bound to run the real risk of being partially, though significantly, incomplete.

And with that, I rest my case.

\section{ABBREVIATIONS}

\section{ANCL L'Antiquité classique}

AS Archaeology and Science

$C M L B$ Duhoux, Yves and Morpurgo Davies, Anna, eds. A Companion to Linear B: Mycenaean Greek Texts and their World. Vol. I. Bibliothèque des Cahiers de l'Institut de Linguistique de Louvain 120). Louvaine-la-Neuve, France: Peeters, (C) 2014. 292 pp. ISBN 978-2-7584-0192-6 (France) FAV Faventia: Revista de filologia clássica KADM Kadmos: Zeitschrift für Vor- und Frühgriechische Epigraphik
KTMA KTEMA, civilisations de l'orient, de la Grèce et de Rome antique

MIN Minos: Revista de Filología Egea. ISSN: 0544-3733

MINR Minerva: Revista de Filología Clasíca

PALM Palmer, L. R. The Interpretation of Mycenaean Texts. Oxford: Oxford University Press. 1963. Special Edition for Sandpiper Books Ltd., (C) 1998. xiii, 488 pp.

PASI Pasiphae: Rivista di filologia e antichità egee

\section{BIBLIOGRAPHY}

\section{Bennet, J. 1990}

"Collectors" or "Owners"? An Examination of Their Possible Functions Within the Palatial Economy of LM II Crete, MYK 1992: 65-101

\section{Chadwick, J. 1958}

The Decipherment of Linear B. Cambridge University Press.

\section{Chadwick, J. 1976}

The Mycenaean World. Cambridge University Press.

\section{Chadwick, J. 1987}

Linear B and Related Scripts (Reading the Past, Vol. 1). University of California Press.

\section{Chadwick, J. and Ventris, M. 1953, 2015}

Documents in Mycenaean Greek. Three Hundred Selected Tablets from Knossos, Pylos and Mycenae with Commentary and Vocabulary. London: Cambridge University Press. Revised Edition, 2015.

Chadwick, J., Killen, J. and Olivier, J. P. 1971

The Knossos Tablets. 4th ed. London: Cambridge University Press.

Del Freo, M., Nosch, M-L. and Rougemont, F. 
2010

The Terminology of Textiles in the Linear B Tablets, Including Considerations on Linear A Logograms and Abbreviations, Michel, C. and Nosch M.-L.: 338-373 in: Textile Terminologies in the Ancient Near East and Mediterranean from the Third to First Millennia BC: Oxbow Books.

Duhoux, Y. 1976

Aspects du vocabulaire économique mycénien ( cadastre - artisanat - fiscalité ). Amsterdam: A. M. Hakkert.

\section{Finley, M. I. 1957}

The Mycenaean Tablets and Economic History, ECR 10: 128-141.

\section{García, C. V. 2002-2003}

Industria y comercio en la sociedad Micénica, MINR: 11-37.

\section{García, C. V. 2014}

Po-ti-ni-ja si-to-Po-ti-ni-ja en las inscripsciones en Lineal B de Micenas: 189-199 in, Bernabé, Alberto \& Luján, Eugenio R., eds. Donum Mycenologicum: Mycenaean Studies in Honour of Francisco Aura Jorro: Peeters, Louvaine-la-Neuve.

\section{Janke, R. V. 2016}

An Archaeologist's Translation of Pylos Tablet TA 641-1952, with an Introduction to Supersyllabograms in the Vessels \& Pottery Sector in Mycenaean Linear B, AS No. 10 (2014): 133-161.

\section{Killen, J. T. 1985}

The Linear B Tablets and Mycenaean Economy, in Morpurgo, Davies A. \& Duhoux Y., eds. Linear B: A 1984 Survey: Proceedings of the Mycenaean Colloquium of the VIIIth Congress of the International Federation of the Societies of Classical Studies (Dublin, 27 August -1st September 1984). Louvain-La-Neuve: Peeters.

Killen, J. T. 2008
A Note on the Knossos Mc Tablets, FAV 2008, 30

(1-2): 47-52

\section{Killen, J. T. 2014}

Mycenaean economy, CMLB. Vol. I.

\section{Killen, J. T. and Olivier, J.-P. 1965}

The Knossos Tablets. A Transliteration, ANCL 34, no 1: 292-294.

\author{
Mavridis, Dimitrios, G. 1972 \\ On the Knossos Mc Tablets, MIN 13, 1972: 29-54.
}

\section{Melena, José L. 1987}

On the Linear B Ideogrammatic Syllabogram ZE: 389-457, in Killen J. T., Melena L., Olivier J.-P, eds., Studies in Mycenaean and Classical Greek presented to John Chadwick, Salamanca, pp. 389457, MIN, 1987: 20-22.

Melena, J. L. 2014

$\S$ 17.4.5.4 'The Adjuncts', pp. 130-152 in Chapter 17, "Mycenaean Writing" in, Duhoux, Yves and Morpurgo Davies, Anna, eds. A Companion to Linear B: Mycenaean Greek Texts and their World. Volume 3. Louvaine-la-Neuve, France: Peeters

Morwood, J. and Taylor J. 2002

Pocket Oxford Classical Dictionary. Oxford: Oxford University Press.

\section{Nosch, M. Louise B. 1998}

L'administration des textiles en Crète centrale, hors les séries Lc/Le/Ln, BCH : 2. Études chroniques et rapports. 122: 404-406.

\section{Nosch, M. L. B. 2001}

Entre collecteurs et travailleurs : 'les responsables' dans l'industrie textile de Cnossos, KTMA. $\mathrm{N}^{\mathbf{0}}$. 26: 133-143.

Nosch, M. L. B. 2008

The Mycenaean Palace-Organised Textile Indus- 
try, pp. 135-154 in Perna, Massimo \& Pomponio, Francesco, eds. The Management of Agricultural Land and the Production of Textiles in the Mycenaean and Near Eastern Economies. (Studi egei e vicinorientali. 4) Paris: De Brocard.

Nosch, M. L. B. 2009

Les allocations de laine des tablettes en Linéaire $\mathrm{B}$ de Thèbes, KADM, Band 48: 77-92.

\section{Olivier, J.-P. 1999}

El comercio micénico desde la documentación epigráfica, MIN 31-32: 275-292.

\section{Palmer, L. R. 1963}

The Interpretation of Mycenaean Texts. Oxford: Oxford University Press.

\section{Rougemont, F. 2004}

The Administration of Mycenaean Sheep Rearing (Flocks, Shepherds, 'Collectors'), pp. $243 \mathrm{ff}$. in Frizell, B., ed. Man and Animal in Antiquity. Proceedings of the Conference held in Rome, September 11-15, 2002. Roma: The Swedish Institute in Rome, Projects and Seminars 1.

\section{Rougemont, F. 2006}

Les Porcs dans la documentation mycénienne. Le cas des suidés dans le Proche-Orient ancien, pp. 115-129 in B. Lion et C. Michel (éd.), Travaux de la Maison René-Ginouvès 1, Paris.

\section{Rougemont, F. 2008}

Les enregistrements de l'huile de la série Fh de Cnossos. Essai d'interprétation et de comparaison avec les données du bureau de l'huile à Mar, PASI 2, 2008: 669-689.

\section{Ventris, M. and Chadwick, J. 1973}

Documents in Mycenaean Greek. Cambridge: Cambridge University Press. (2nd. Edition) 2 Vols.

\section{Electronic periodicals (PDF):}

\section{Evans, Sir A. 1909}

Scripta Minoa: The Written Documents of Minoan Crete with Special Reference to the Archives of Knossos. University of Heidelberg. digi.ub.uni-heidelberg.de/diglit/evans 1909ga

\section{García, C. V.}

La Métodologia actual en el Estudio de los Textos Micenicos: un Ejemplo práctico. https://ddd.uab.cat/pub/faventia/.../02107570v12-13p353.pdf: 353-365

\section{Janke, R. V. 2015}

The Rôle of Supersyllabograms in Mycenaean Linear B. Presentation given at The Third Interdisciplinary Conference, "Thinking Symbols", Pultusk Academy of the Humanities, Pultusk, Poland: July 1 2015. In the extremely comprehensive bibliography to this presentation, consisting of 144 items, Marie Louise Nosch is cited from 95-107. Koryvantes, the Association of Historical Studies https://koryvantes.org/studies-in-english-language/page221-2/

\section{Martinotti, Enriqueta et Tina 2007}

Nouvelle interprétation des tablettes mycéniennes. Traduction du Linéaire $B$ dans les tablettes $39=A S 1517$ (LXXXVIII), de Cnosos et $31=A E$ 04 [134], 2007. <hal-00193886v3>: 1-53

\section{Martinotti, Enriqueta et Tina 2008}

Linéaire B : le préjugé comptable et pictographique d'un syllabaire logographique, phonologique et polysémantique. (sans pagination, unpaginated). hal-00311652, version 3-10 sep 2008.

\section{Melena, J. L. 1974}

Olive Oil and Other Sorts of Oil on the Mycenaean Tablets: 89-123. (35 pp.) PDF

http://gredos.usal.es/jspui/bit-

stream/10366/73447/1/Olive Oil and Other Sorts of Oil in the .pdf: 89-123

Palaima, T. 2003

'Archives' and 'Scribes' and Information Hierar- 
chy in Mycenaean Greek Linear B Records. PDF

bmcr.brynmawr.edu/2004/2004-03-42.html . An

Offprint From

Brosius, Mario, ed. 2003. Ancient Archives and Archival Traditions. Concepts of Record-Keeping in the Ancient World. Oxford Studies in Ancient Documents. Oxford: Oxford University Press

Tselentis, C. 2011

Linear B Lexicon. (unpaginated). 2008. No longer online. Ask the author to send you a copy. PDF. This work is licensed under a Creative Commons Attribution-ShareAlike 3.0 Unported License.

\section{Ventris, M.}

The Ventris Papers. Institute of Classical Studies (Series: Collections and Projects: ICS (Michael Ventris Archive). London: University of London, School of Advanced Study. Duplicate copy at Austin: University of Texas. 36.

http://www.icls.sas.ac.uk/research/archives\#VentrisPapers

\section{REZIME DEŠIFROVANJE SUPERSILABOGRAMA U LINEARU B}

\section{KLJUČNE REČI: MIKENSKI LINEAR B， SU- PERSILABOGRAMI, LINEAR B PLOČICE, DEŠIFROVANJE, PREVOD, EKONOMIJA.}

U saradnji sa Asocijacijom za istorijske studije Koryvantes iz Atine, svoju pažnju smo usmerili na fenomen supersilabograma, koji nije valjano identifikovan još od početnog dešifrovanja Mikenskog Linear B pisma 1952. Supersilabogram je prvi silabogram, koji je u kombinaciji sa blisko povezanim ideogramom bio značajan u četiri ekonomska sektora mikenske privrede: poljoprivreda, vojska, tekstil i izrada keramičkog posuđa. Uz vrlo malo izuzetaka, promene u ekonomskom sektoru dovodile su do promena u značenju pojedinih supersilabograma. Od nekih 3500 pločica i fragmenata iz Knososa, oko 800, odnosno 23 \% sadrže barem jedan supersilabogram, a ponekad čak četiri ili pet. Krajnji cilj supersilabograma je eliminisanje teksta na pločicama u najvećoj mogućoj meri. Supersilabogrami su služili da u znatnoj meri uštede dragoceni prostor na malim tablicama koje su bile namenjene za ispisivanje Lineara B. Kompletno dešifrovanje Lineara B mora u potpunosti da uključi supersilabograme kao jedinstveni fenomen, bez kojeg, nedvosmisleno, interpretacija Lineara B ne bi bila dovedena do kraja. 